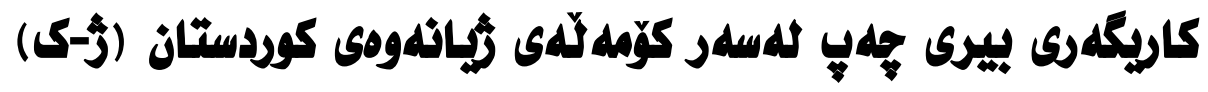 $19 \varepsilon 0-19 \leqslant Y$ \\ تويزّينهوهيهكى ميزّوويى -سياسييه
}

بهشى ميّزوو ، فاكهلّى بهروهرده ، زانكوى كويه ،كويه،ههريّى كوردستان ، عيّراق Ismael.abdalrahman@koyauniversity.org

اسماعيل عبدالرحمان سميد "ئيدال:

هوخته:

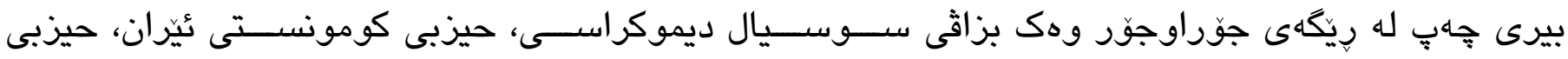

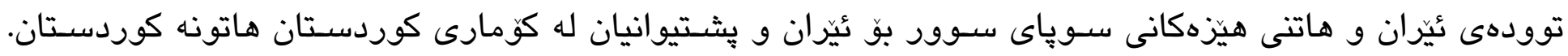

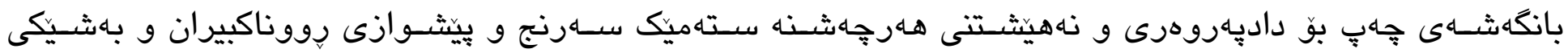

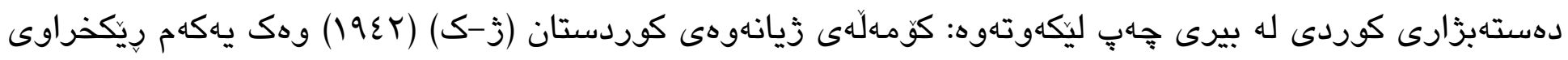

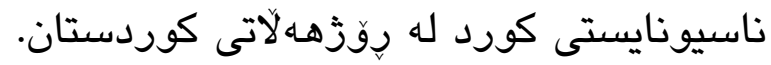

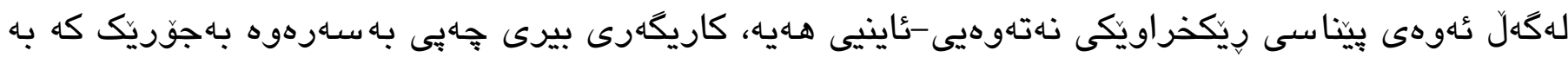

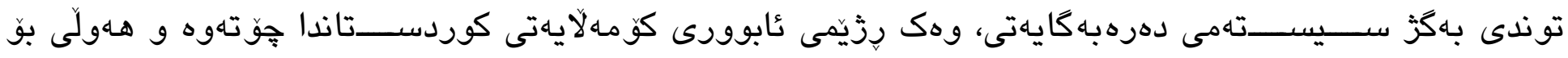

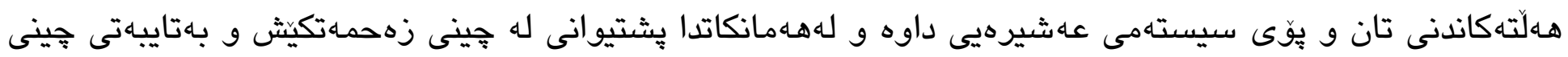

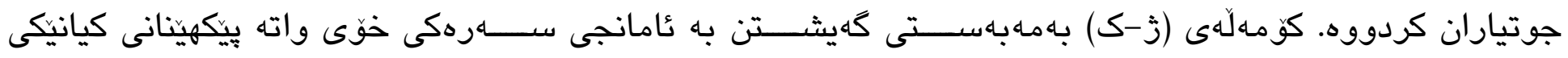

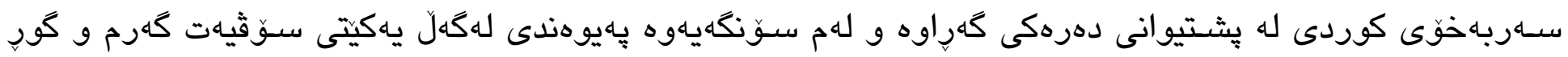

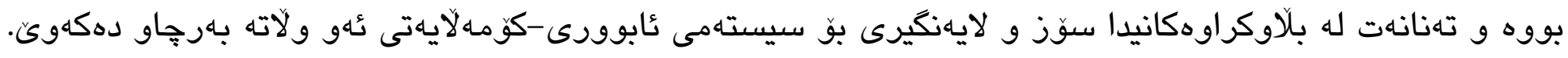

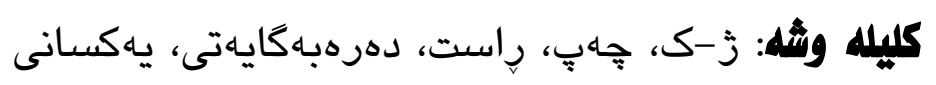




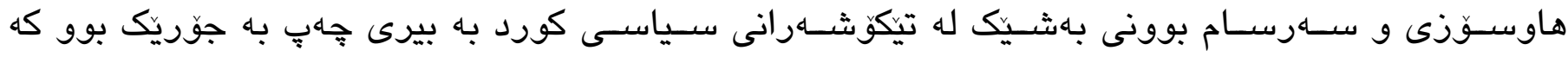

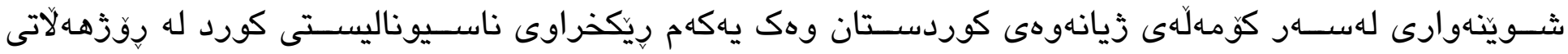

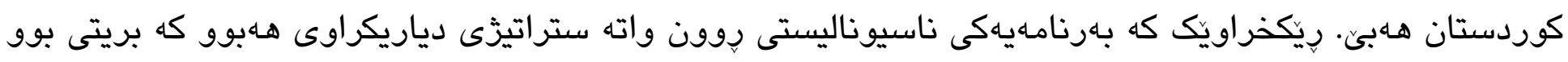

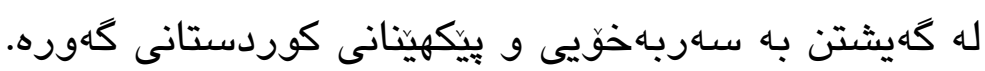

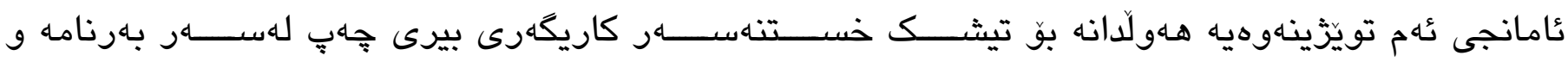

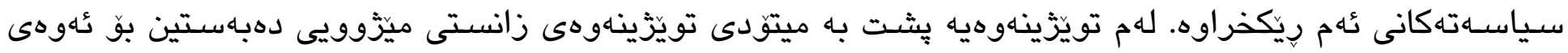

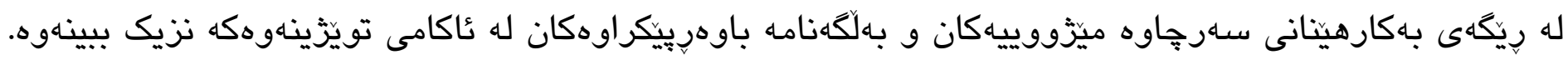

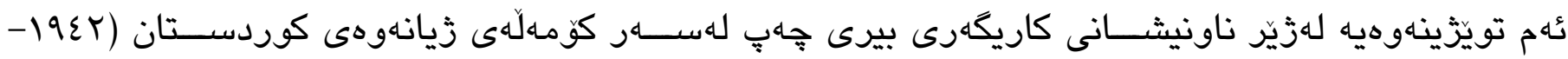

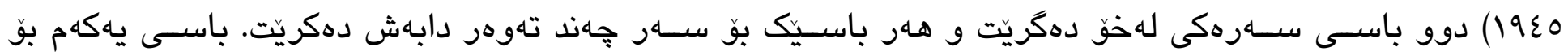

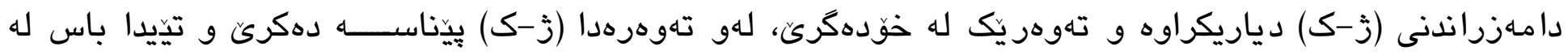

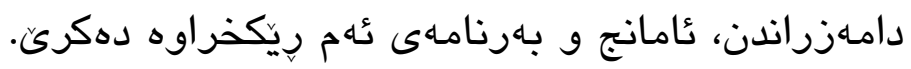

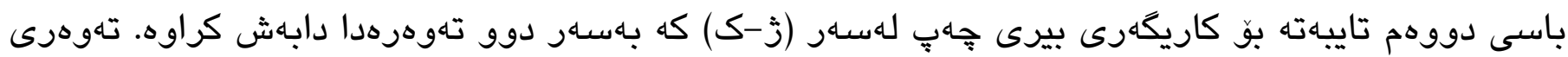

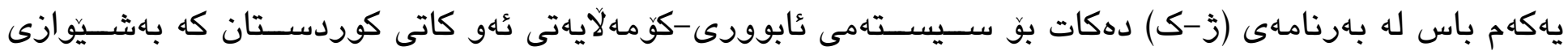

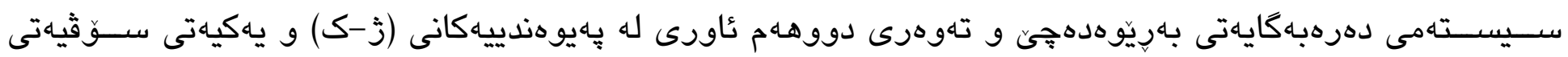
داوهتهوه وهك جهمسـهرى سـهرهكى جيهانى كومونيستى.

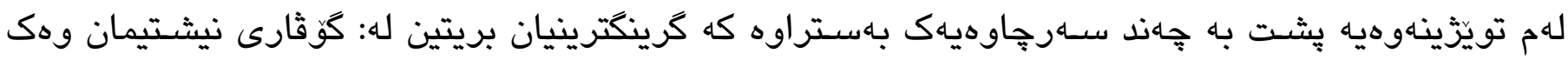

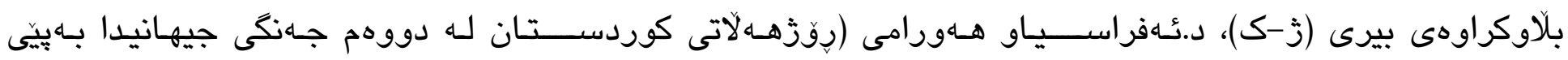

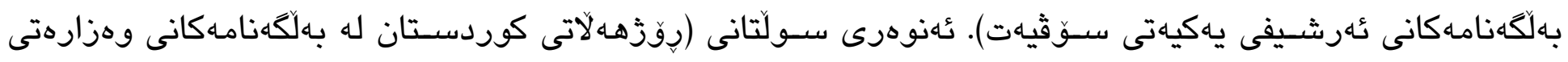

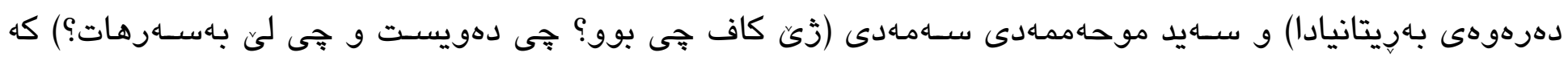

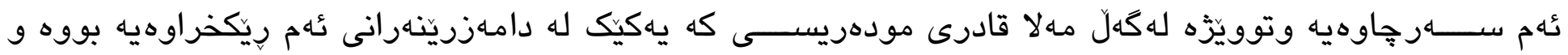

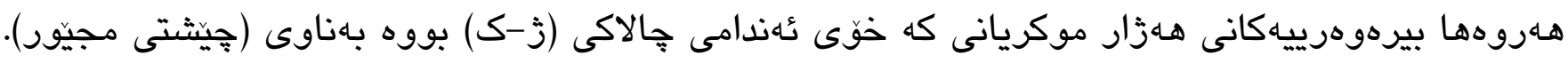

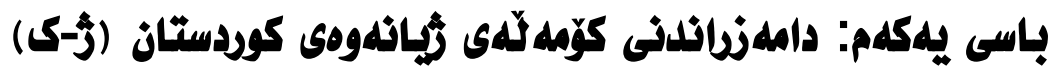

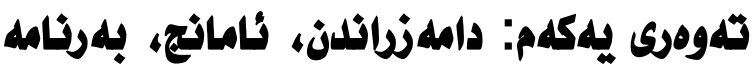

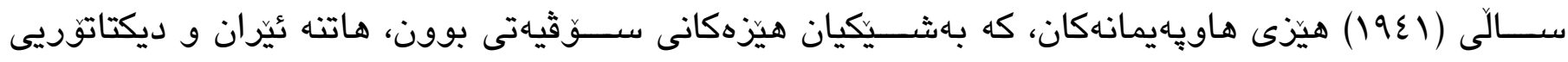

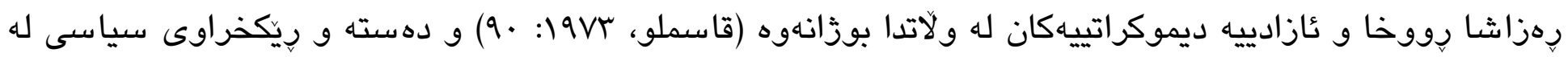

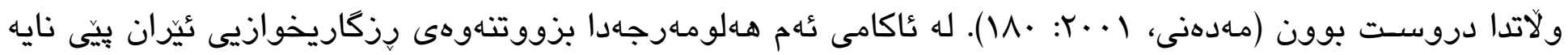

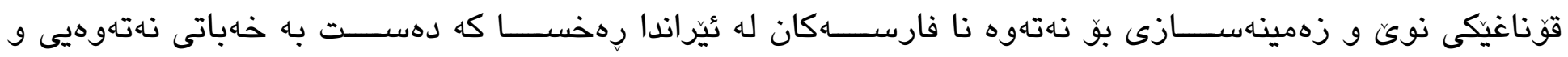

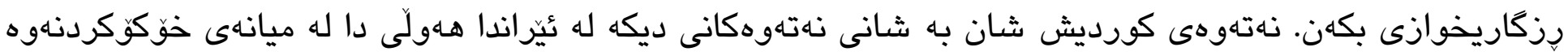

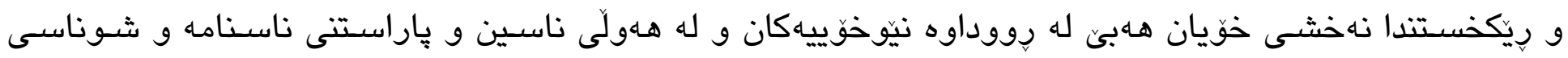

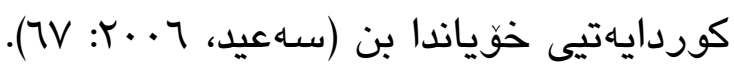




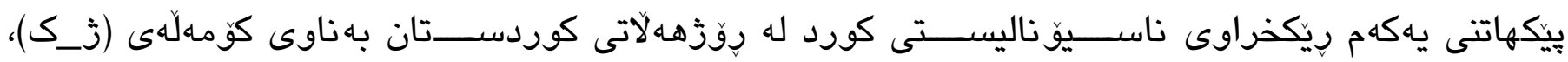

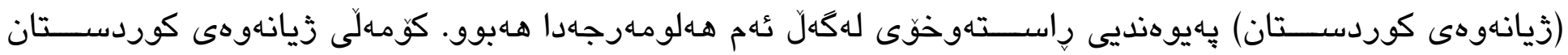

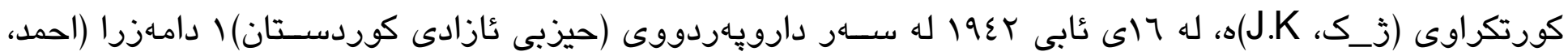

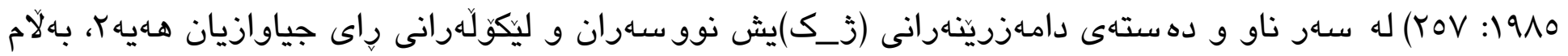

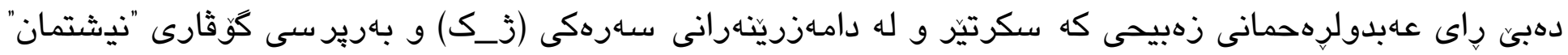

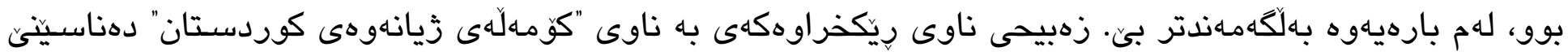

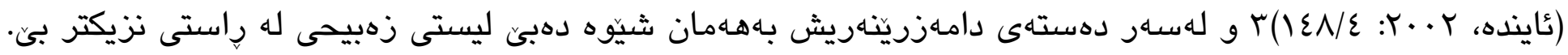

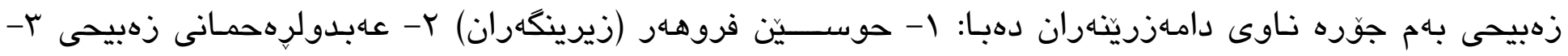

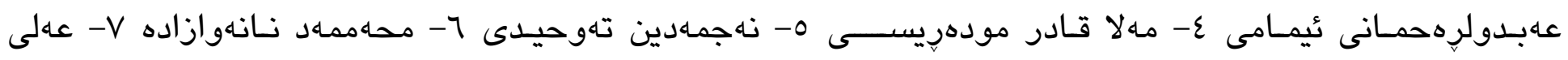

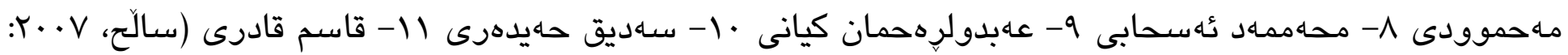
$\varepsilon($ K

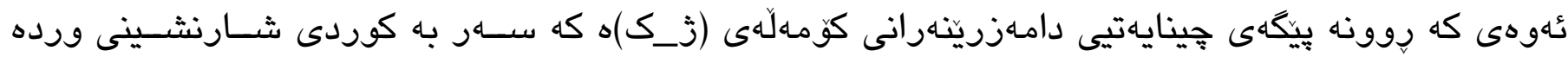

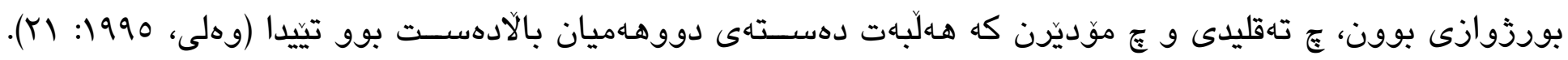

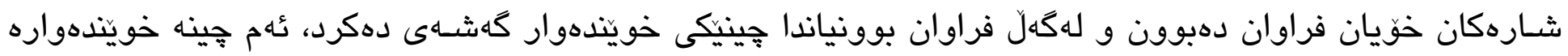

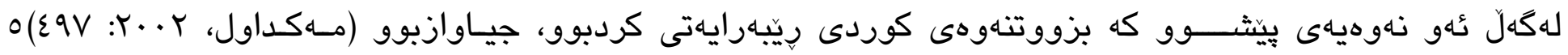

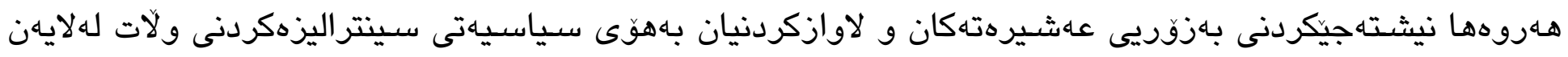

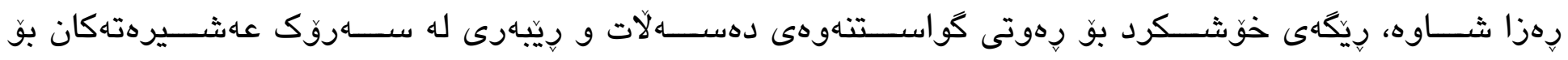

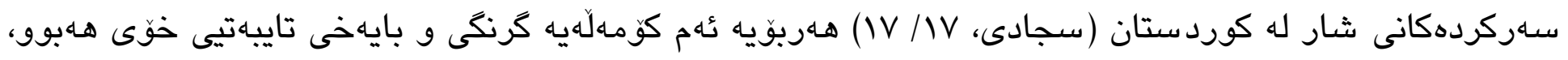

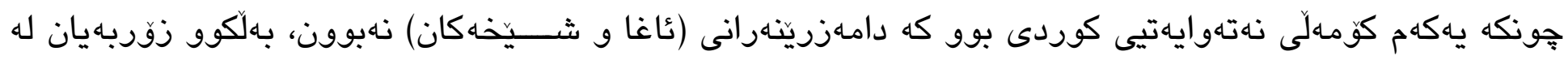

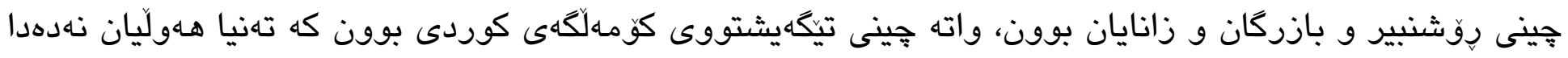

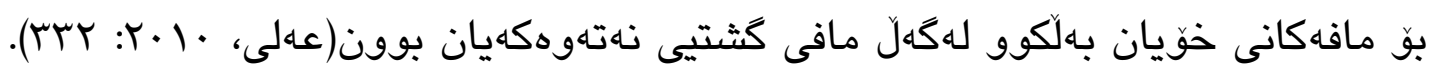

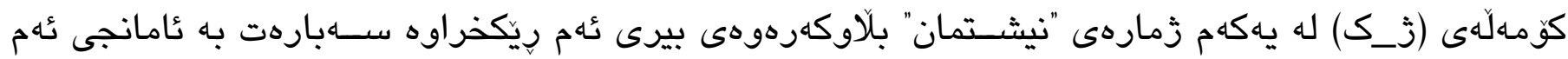
رينيخراوه دهنووسيى:

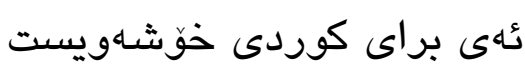

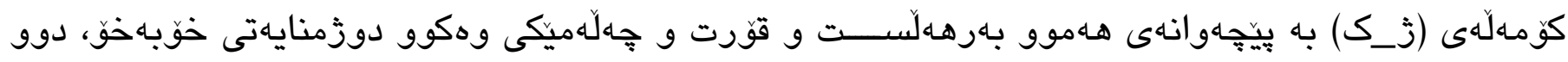

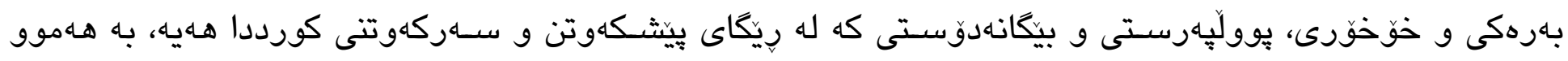

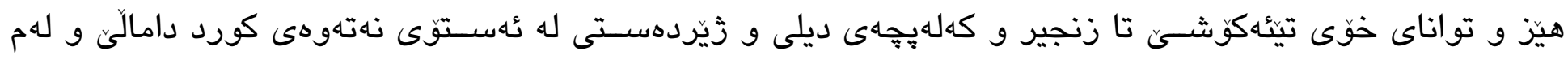

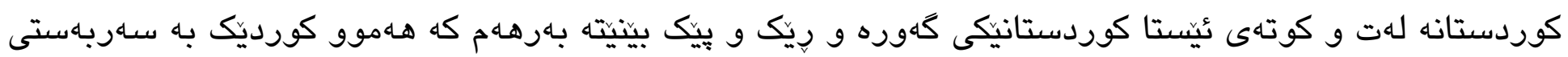

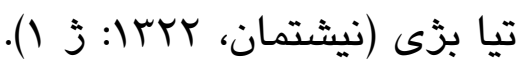

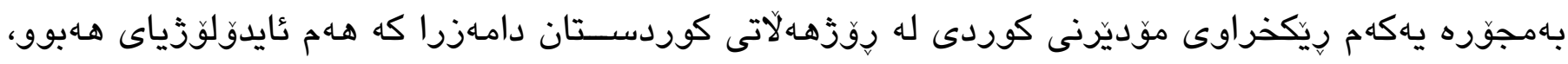

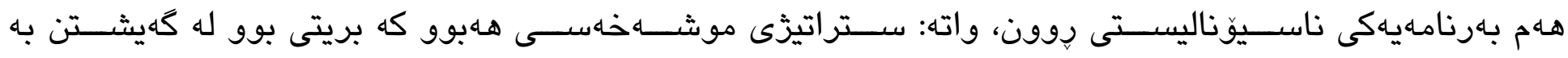

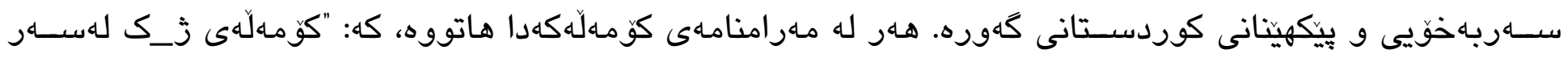

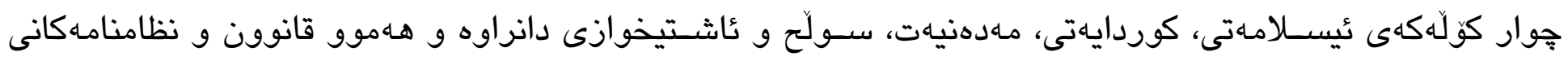

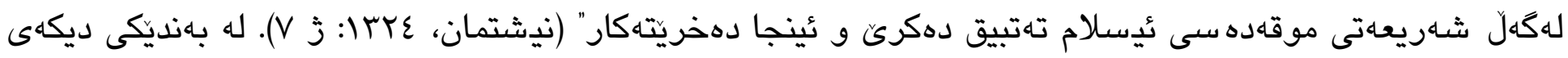




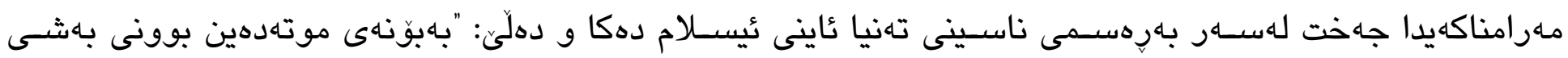

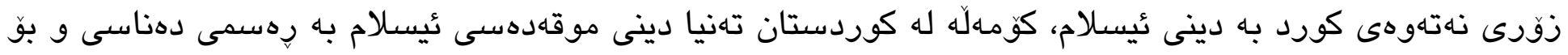

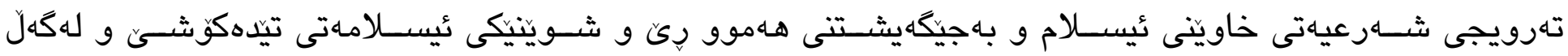

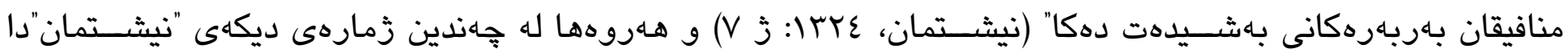

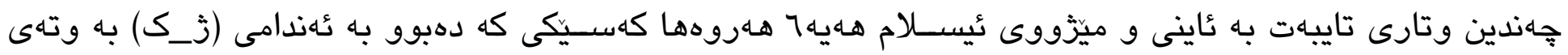

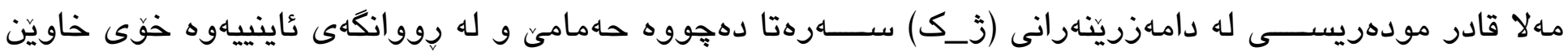

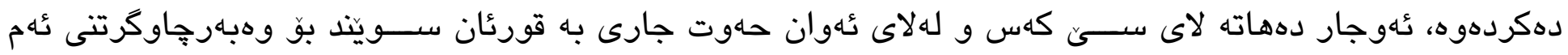

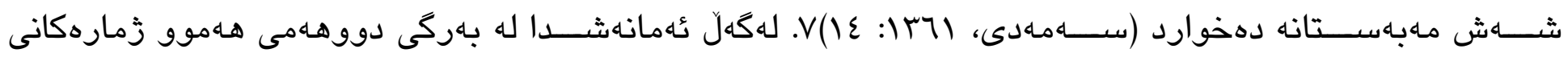

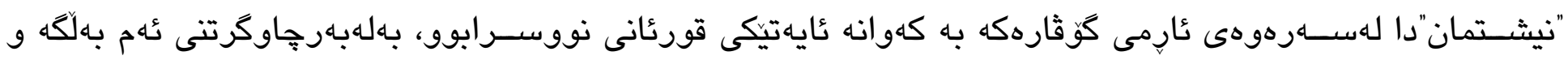

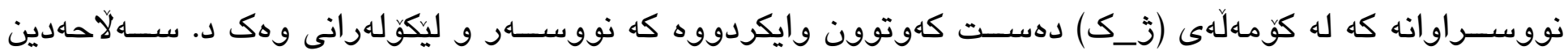

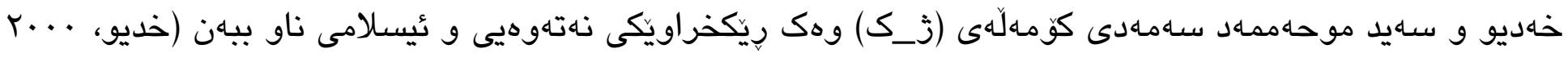

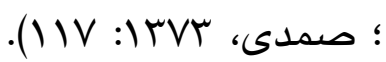

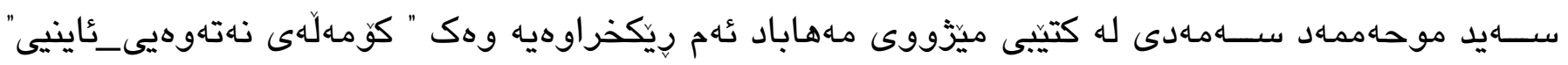

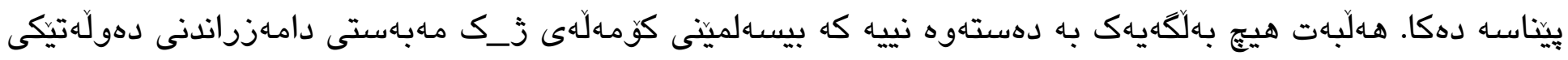

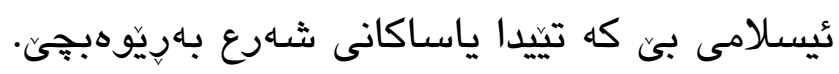

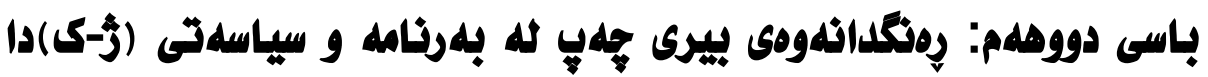

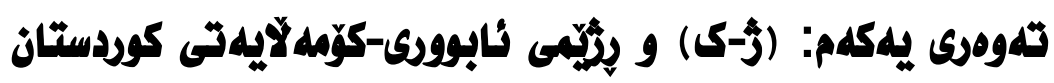

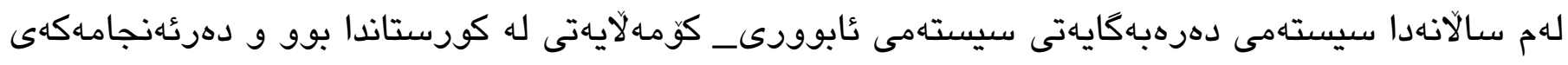

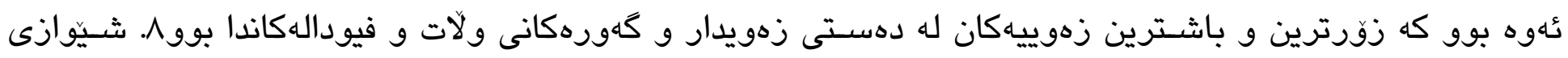

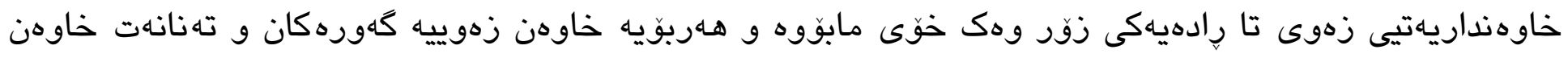

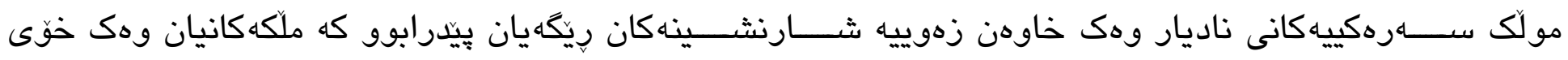

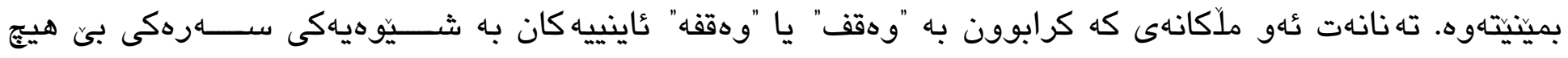

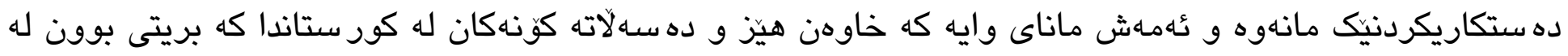

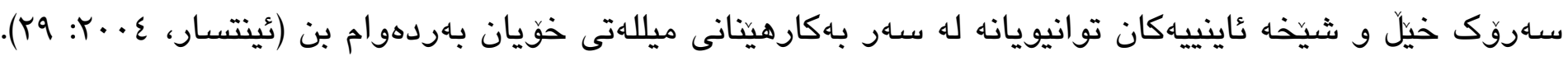

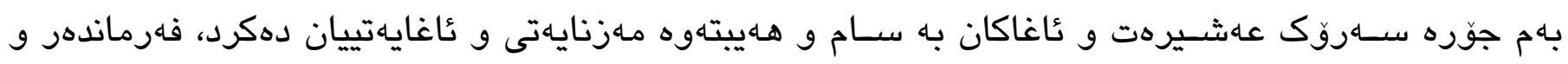

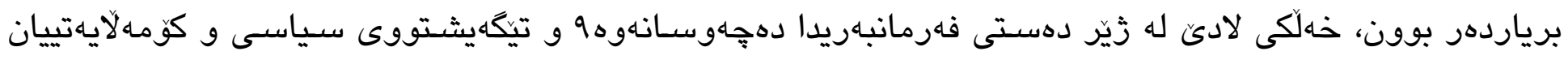

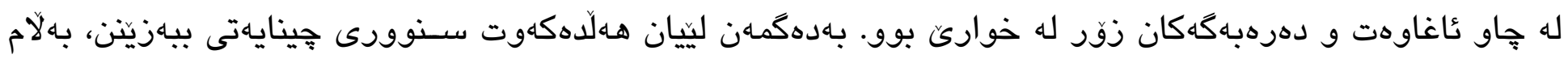

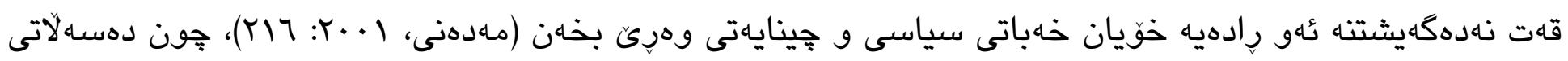

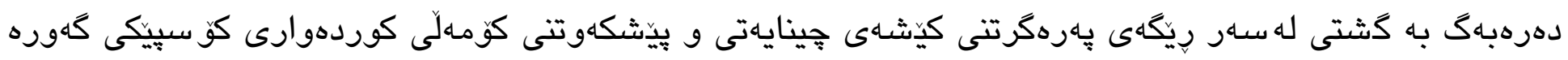

بوو(تاسملو، سلو (: 9 \ع). 


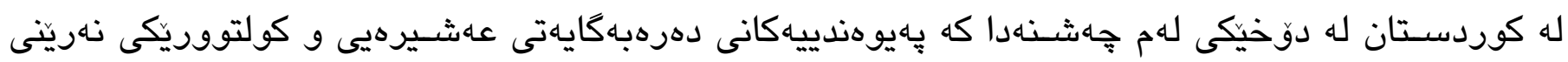

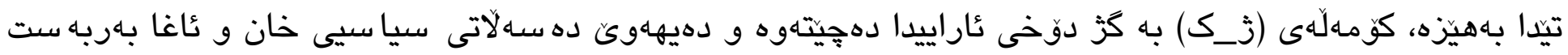

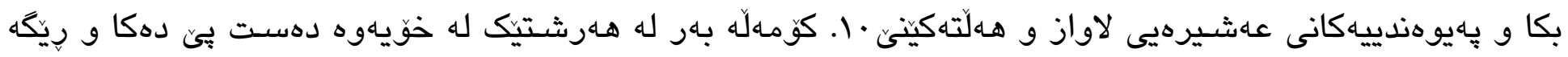

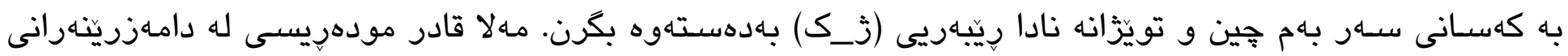

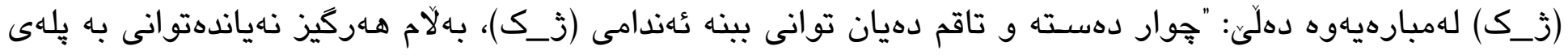

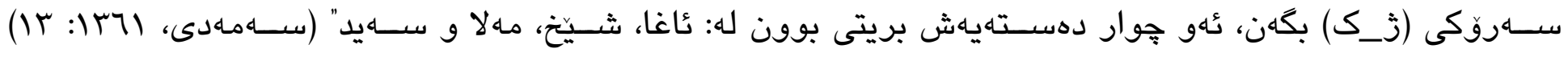

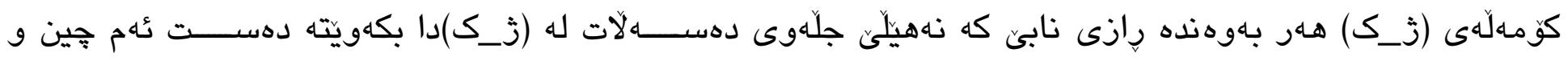

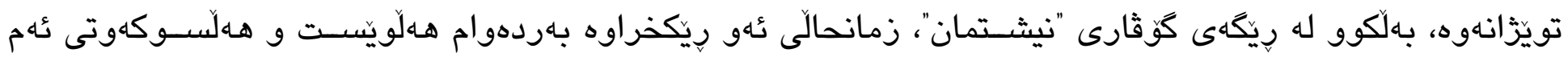

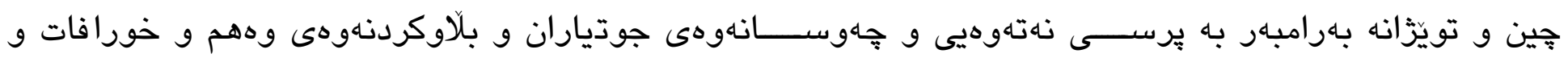

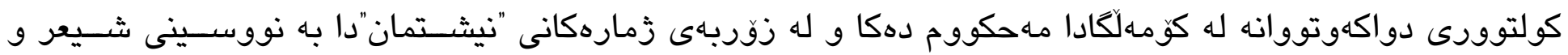

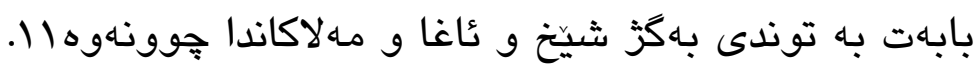

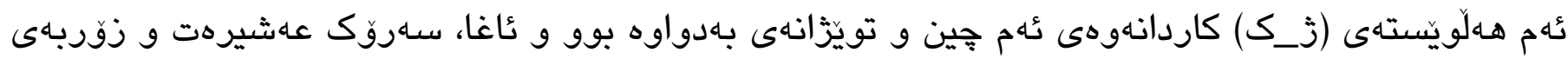

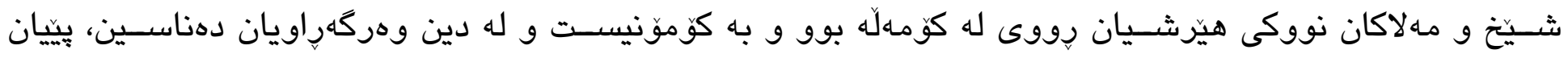

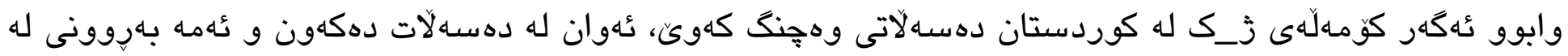

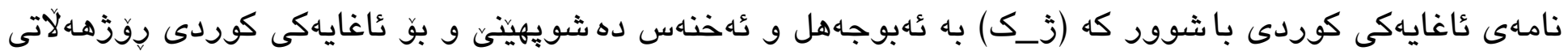

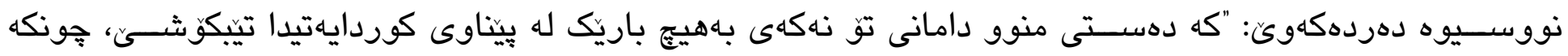

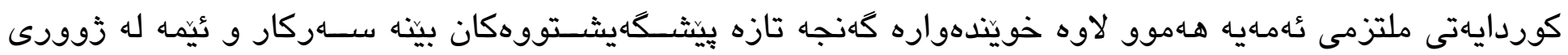

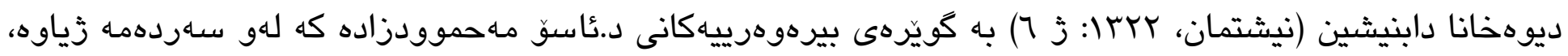

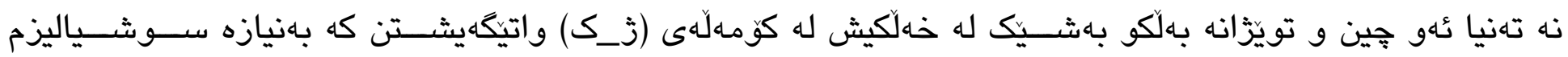
دابماءزرينتين

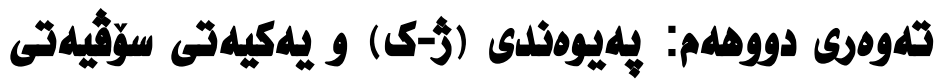

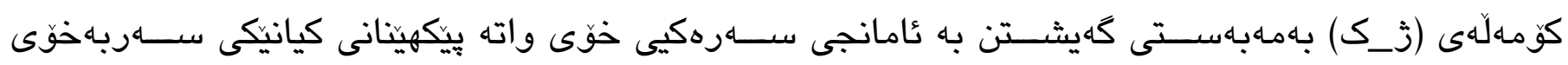

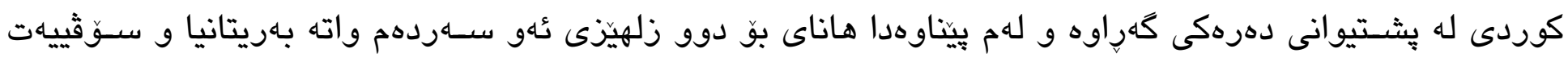

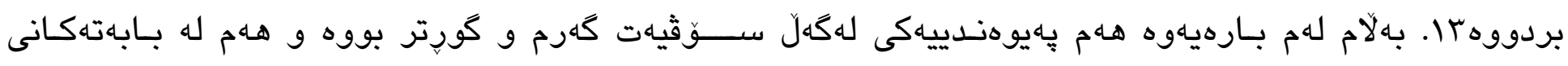

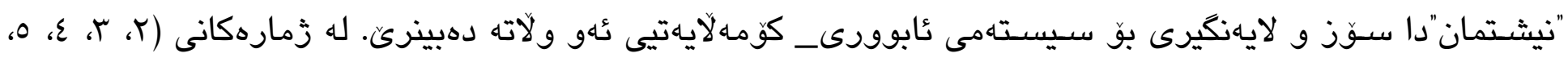

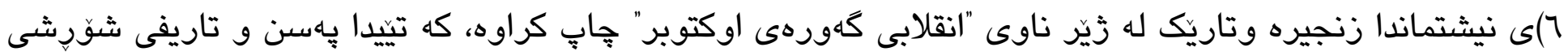

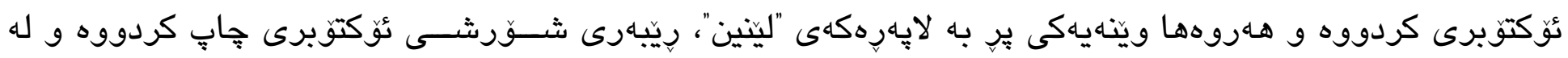

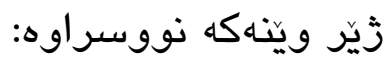

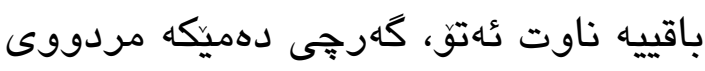

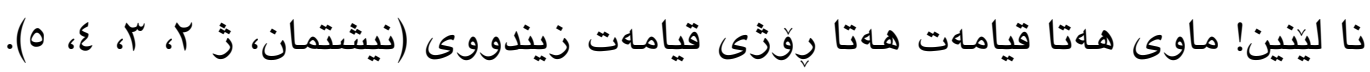

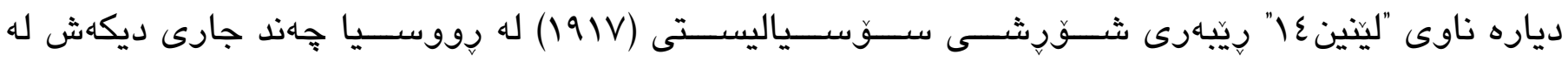

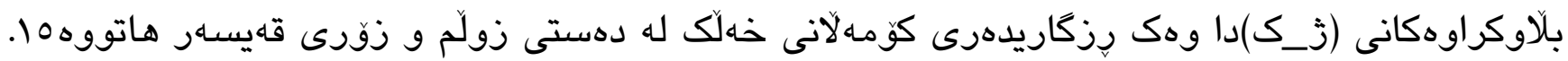




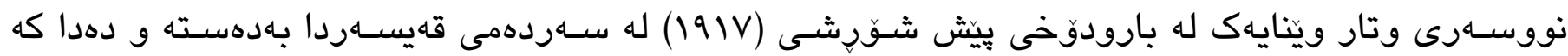

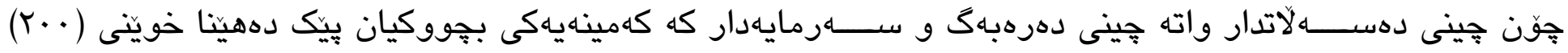

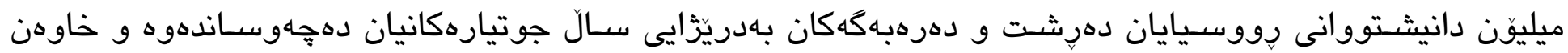

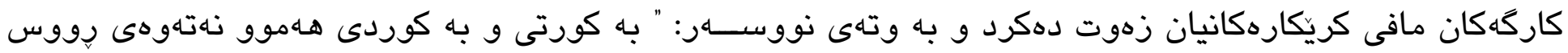

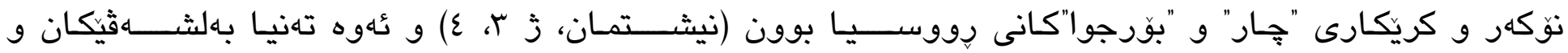

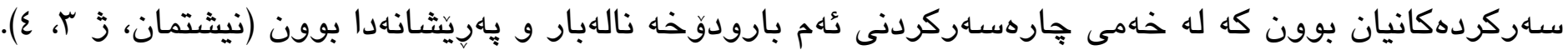

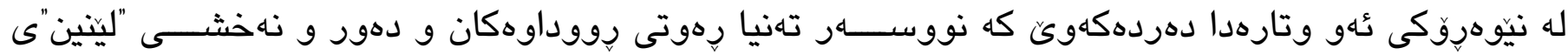

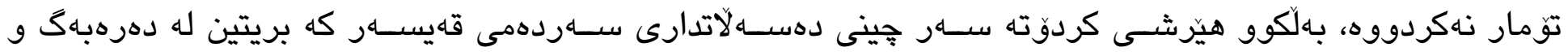

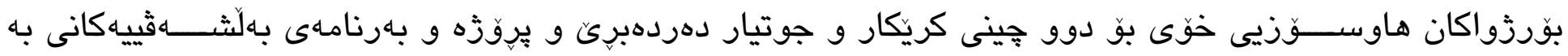

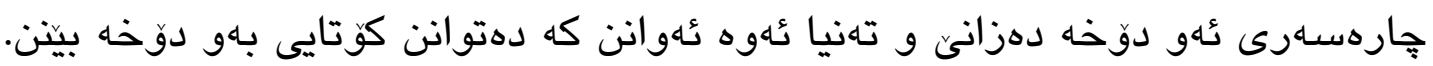

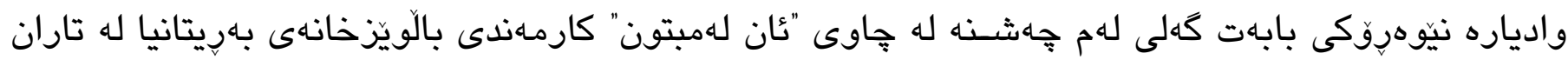

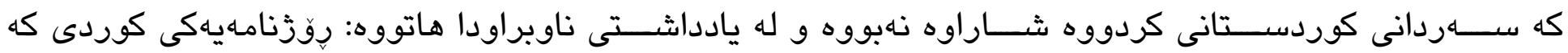

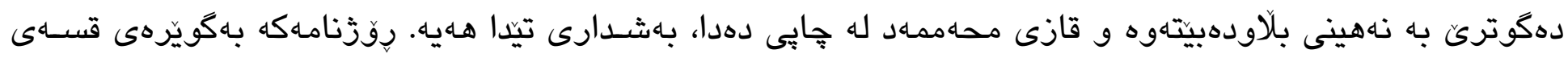

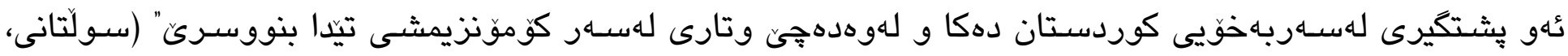

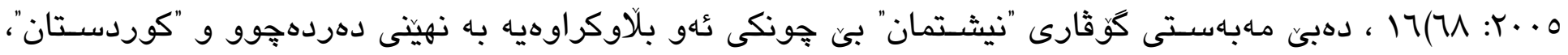

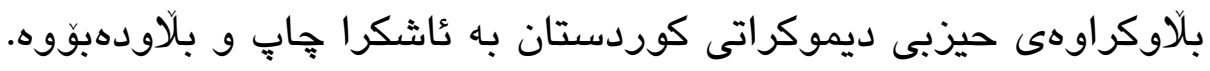

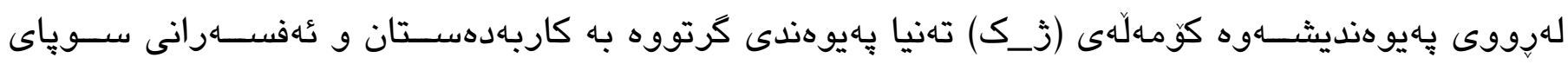

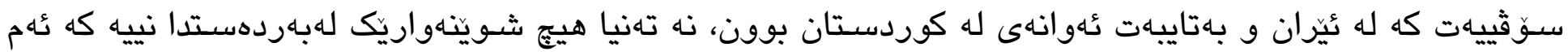

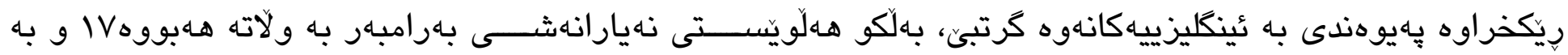

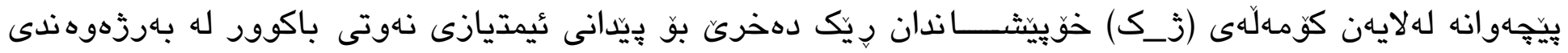

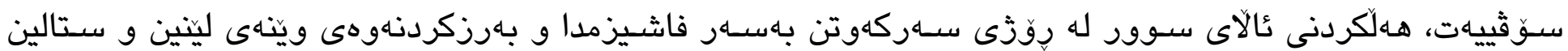

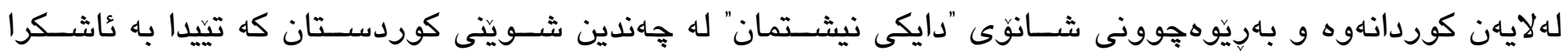

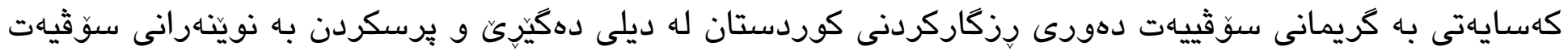

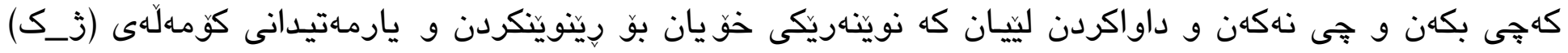

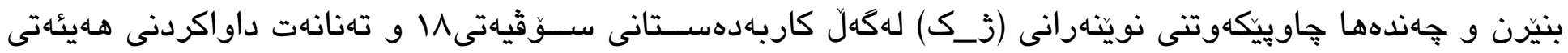

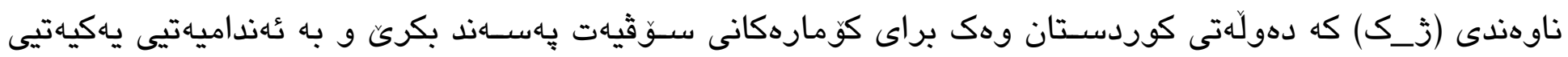

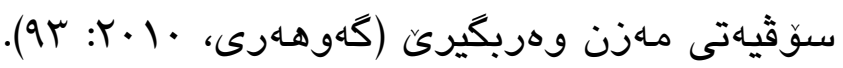

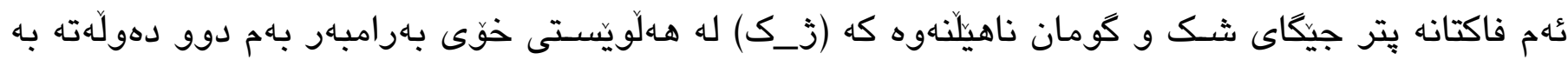

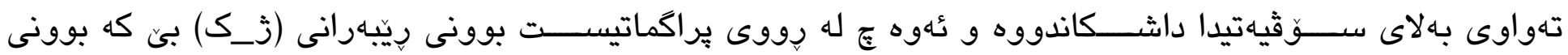

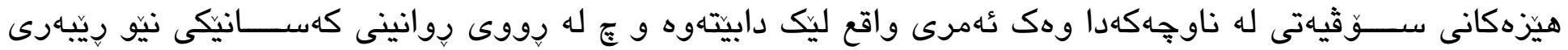

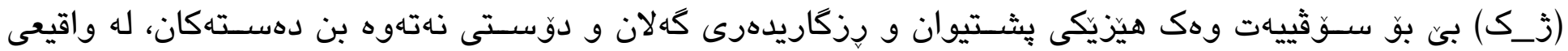

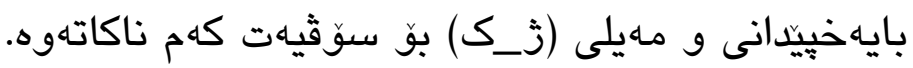

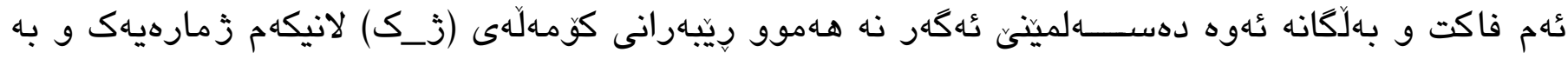

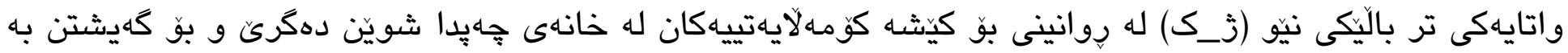




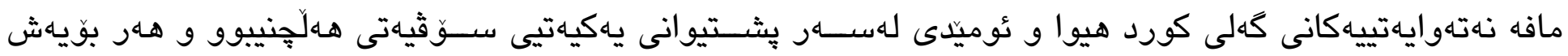

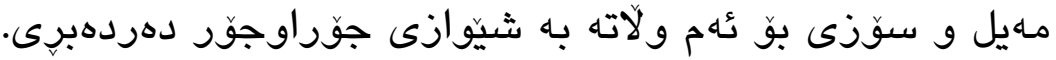

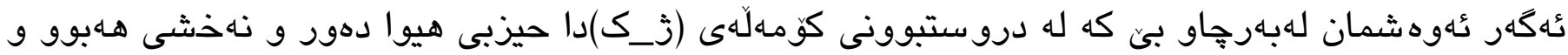

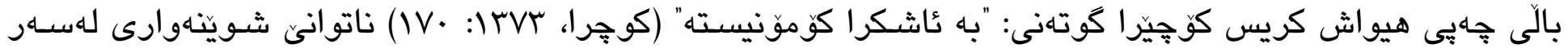

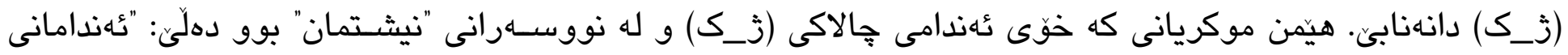

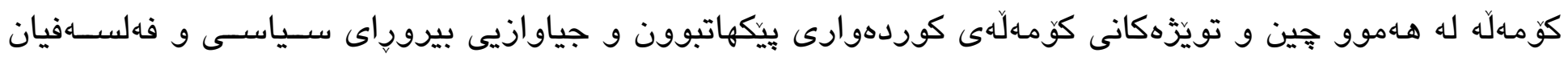

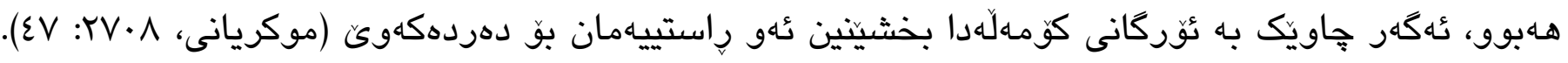

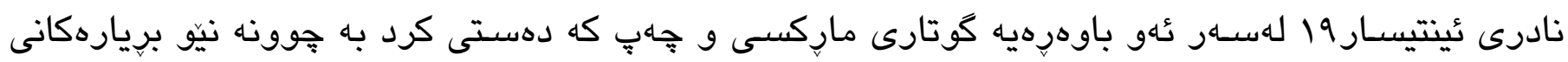

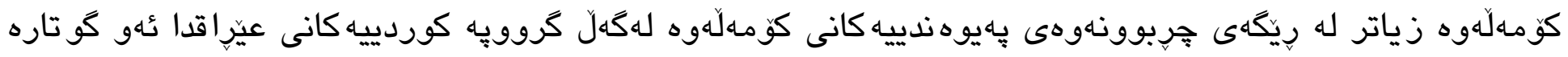

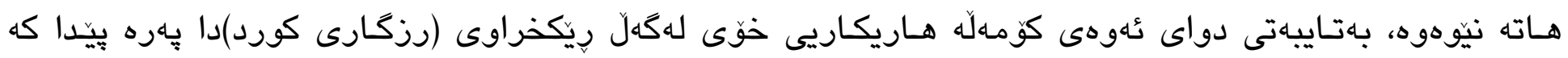

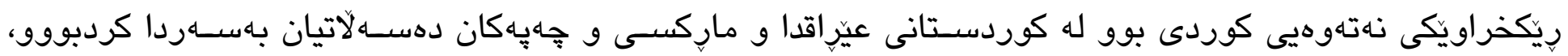

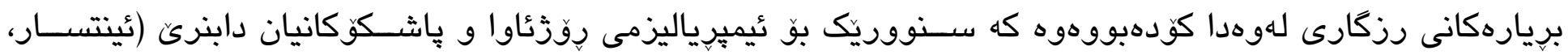

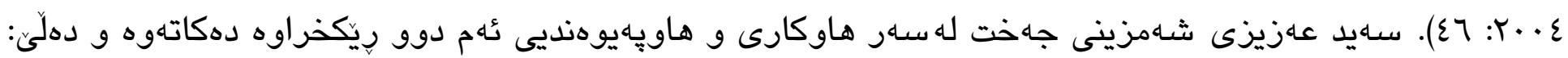

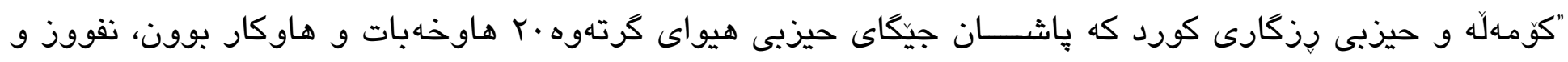

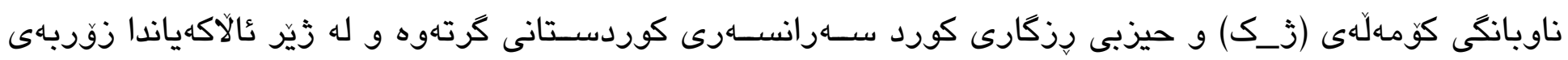

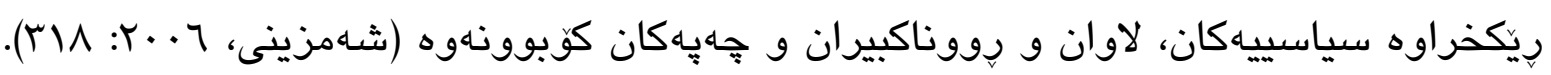

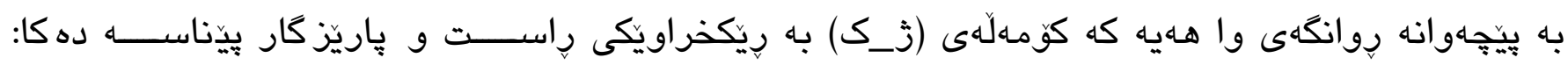

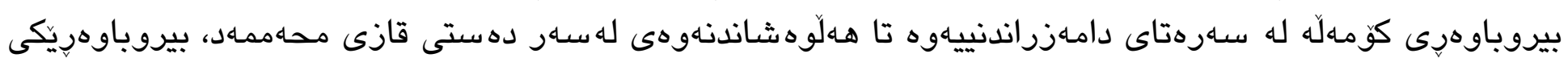

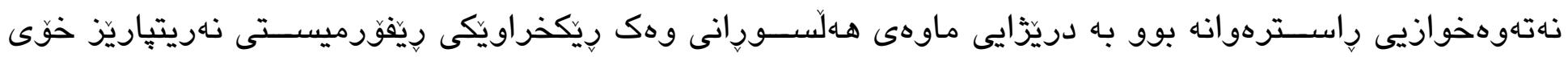

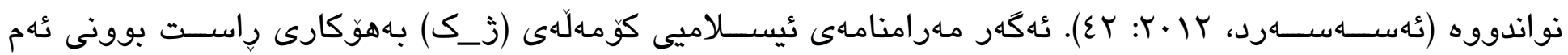

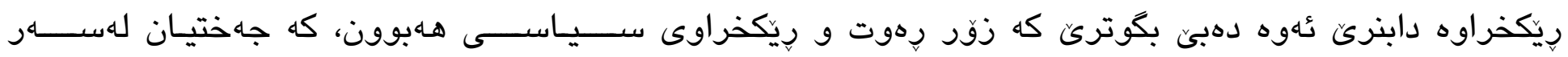

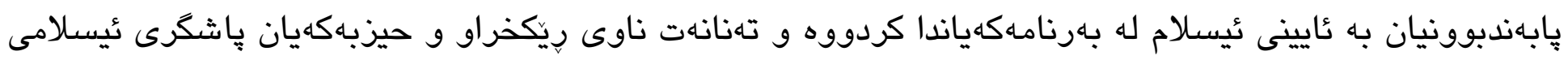

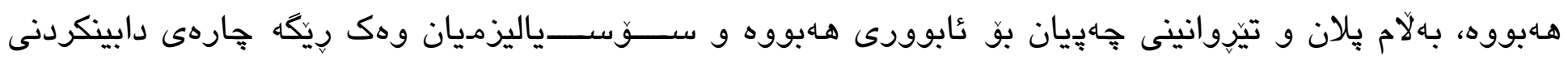

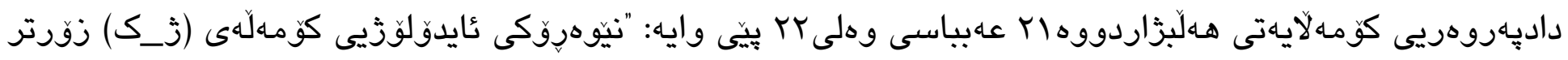

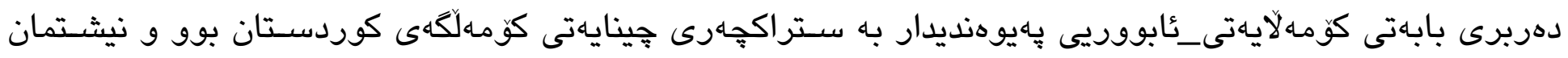

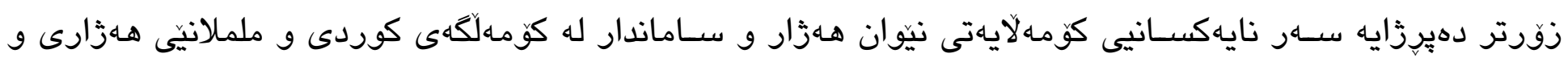

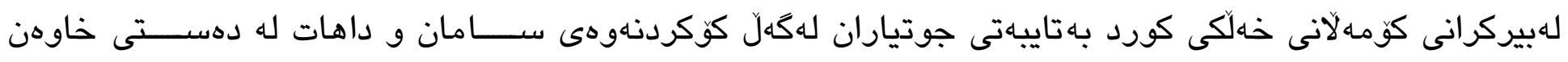

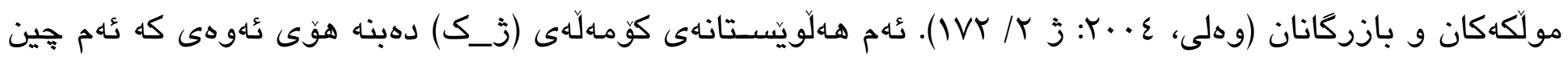

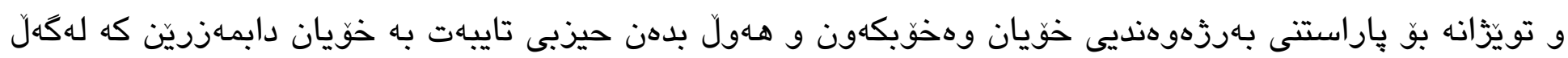

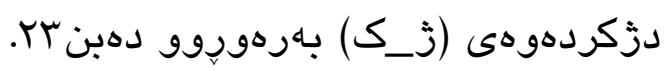

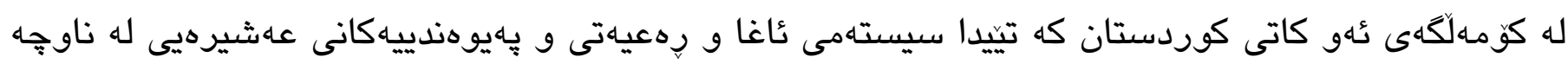

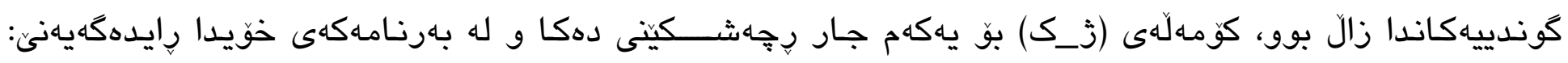

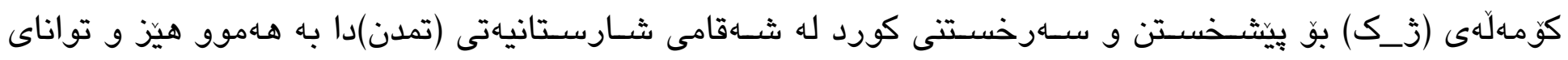

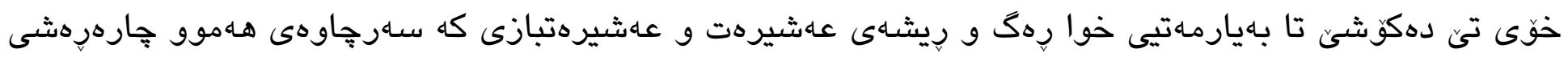




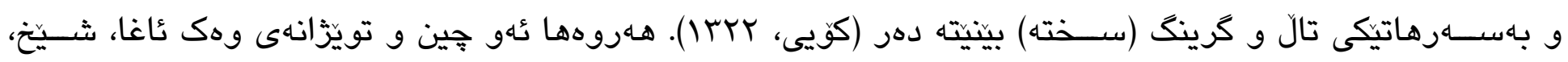

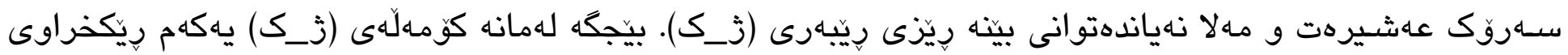

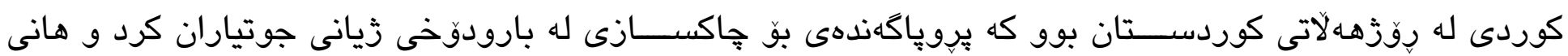

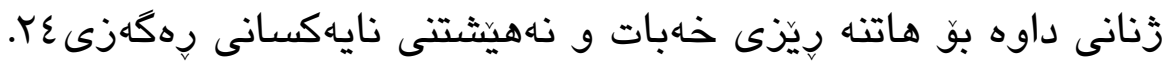

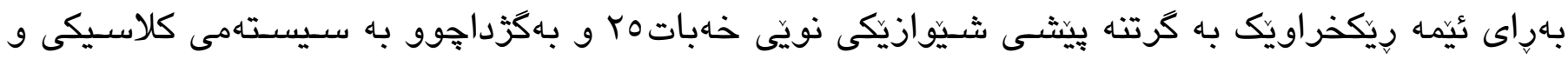

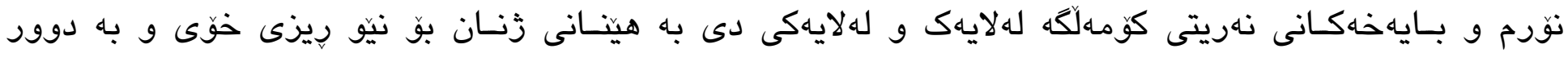

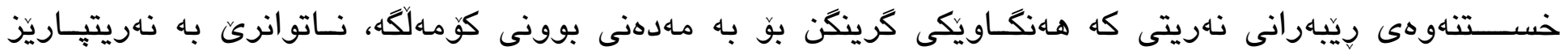

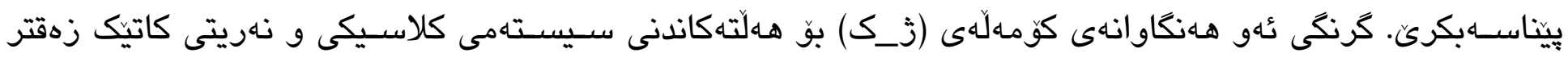

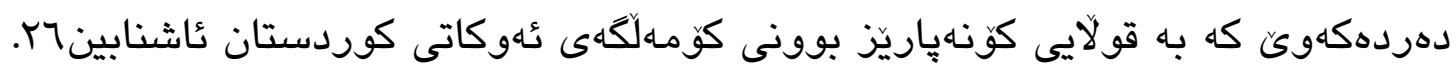

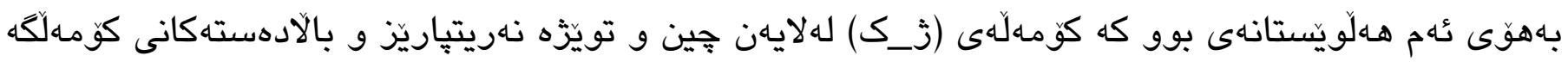

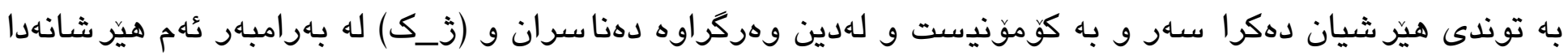

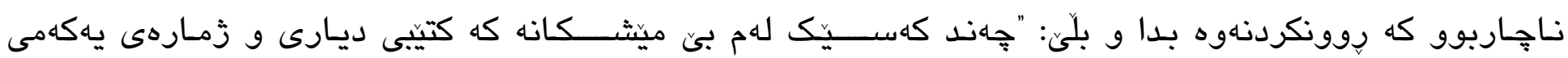

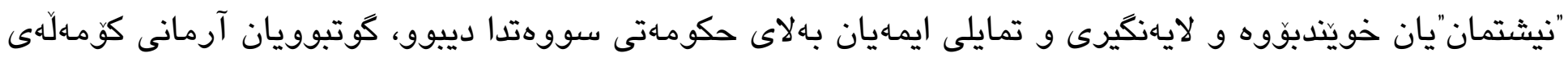

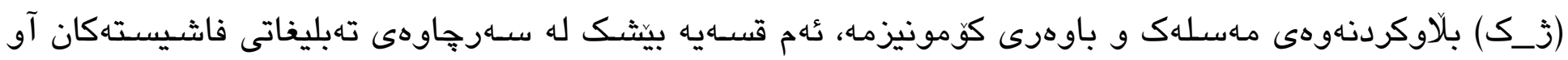

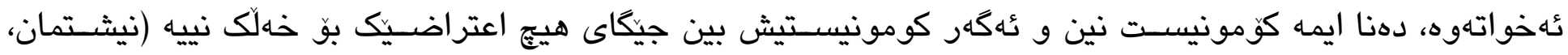

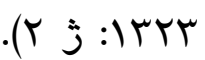

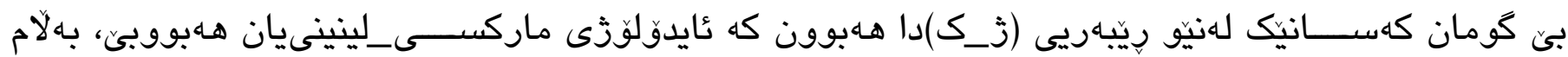

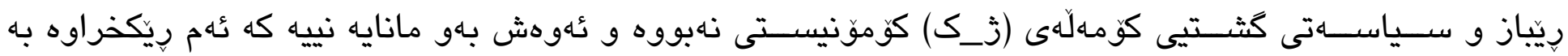

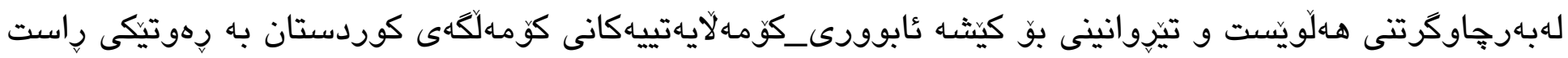

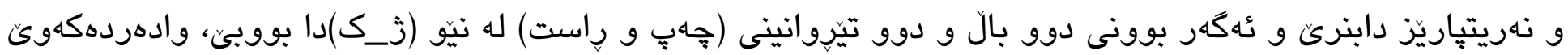

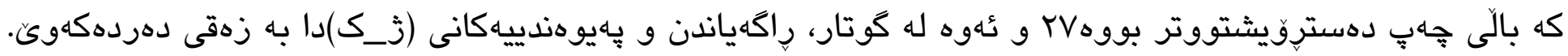

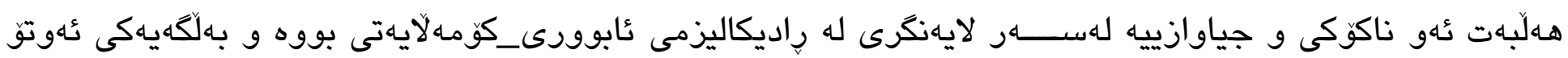

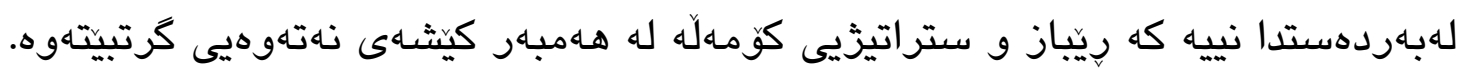




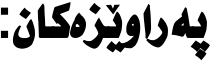

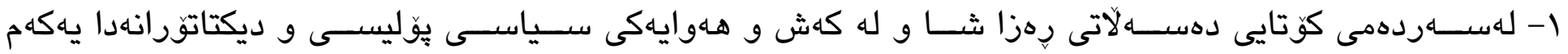

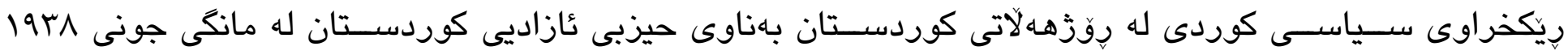

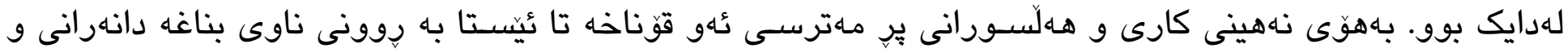

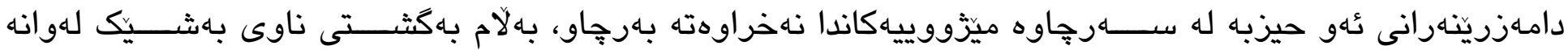

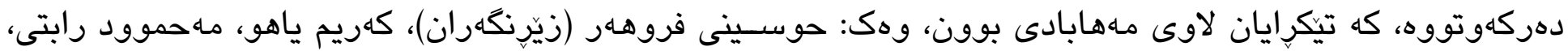

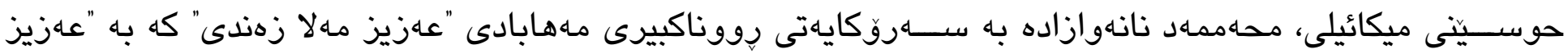

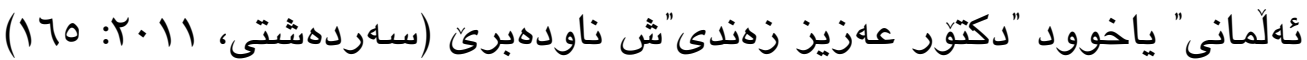

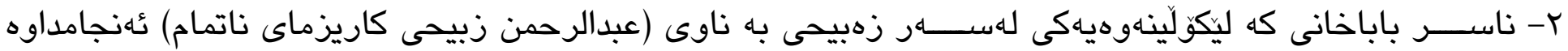

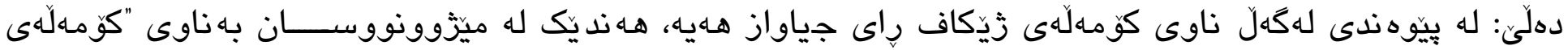

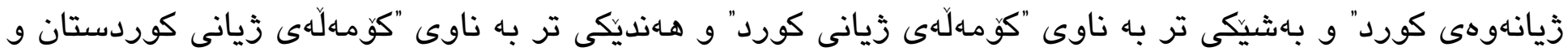

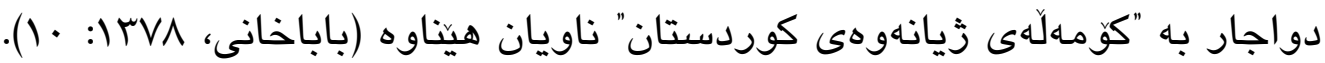

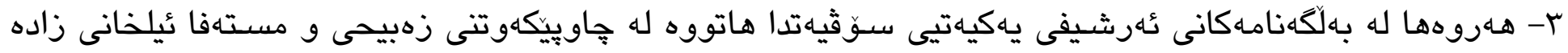

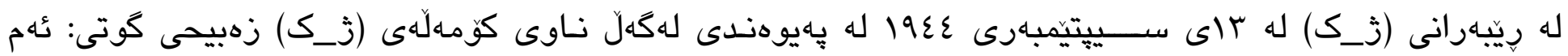

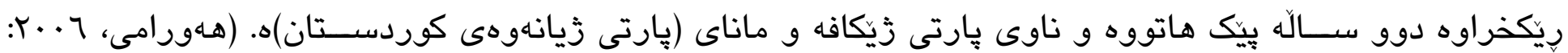

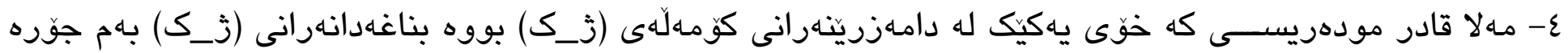

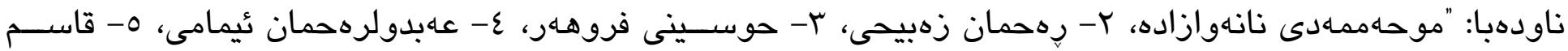

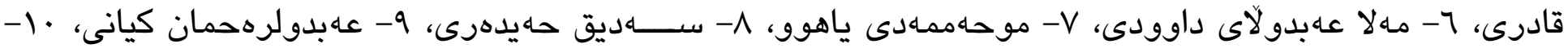

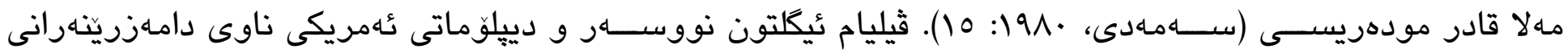

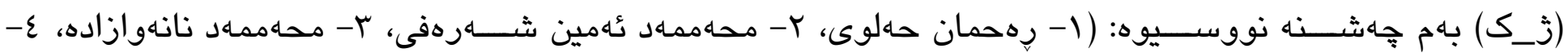

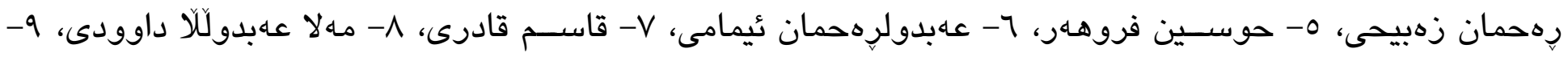

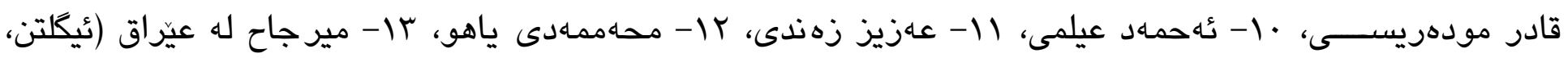

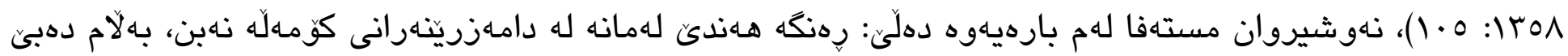

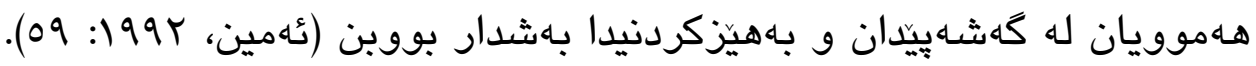

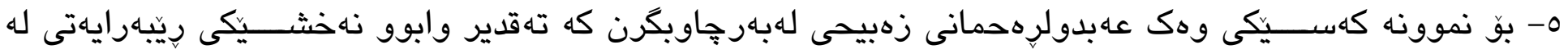

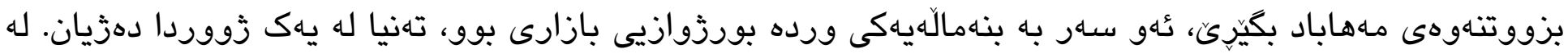

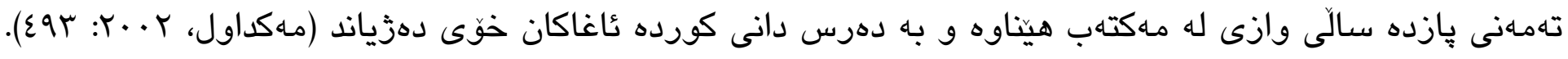

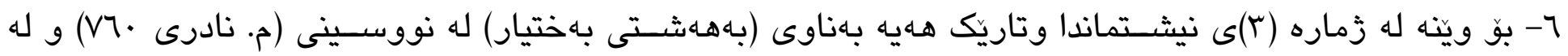

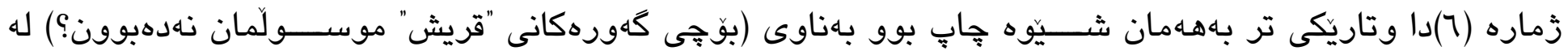

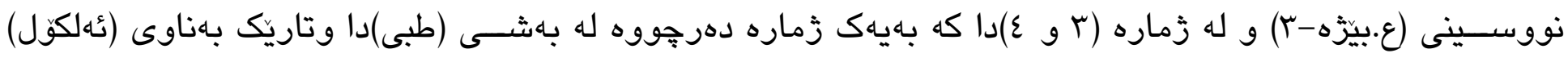

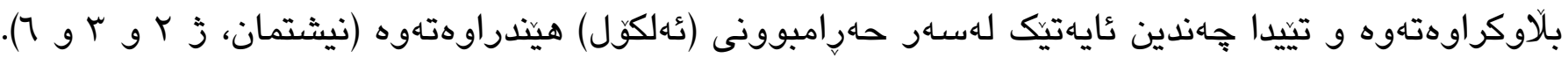




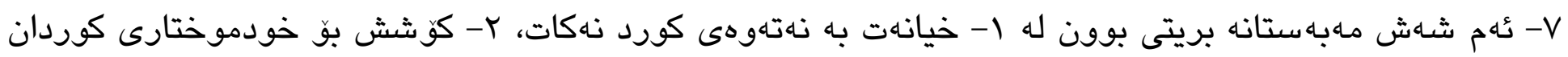

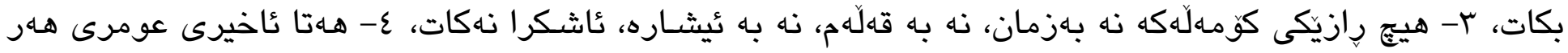

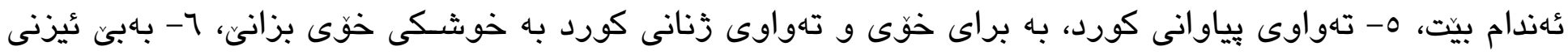

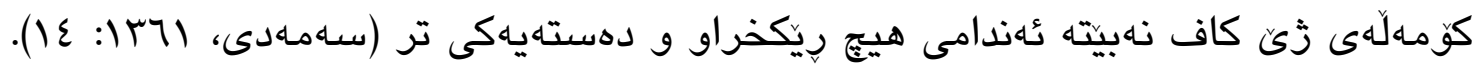

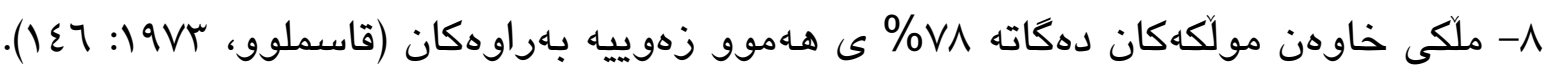

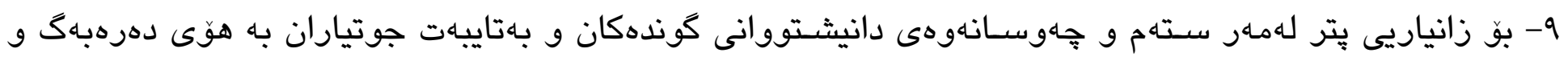

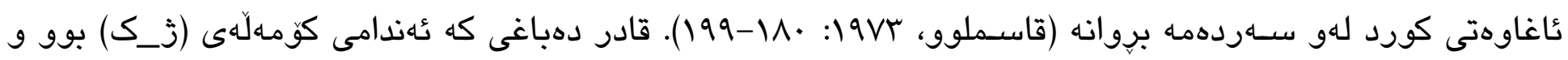

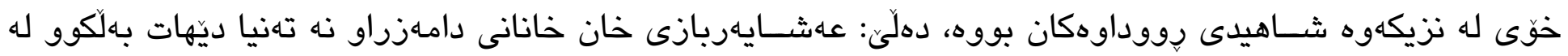

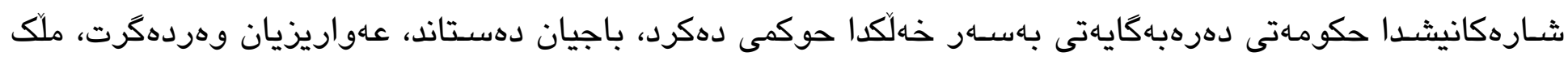

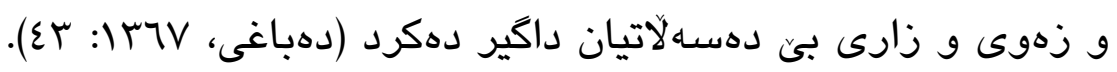

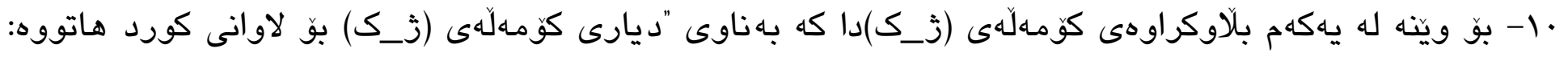

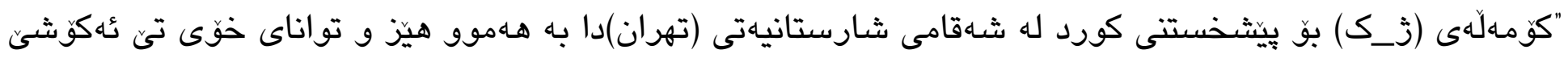

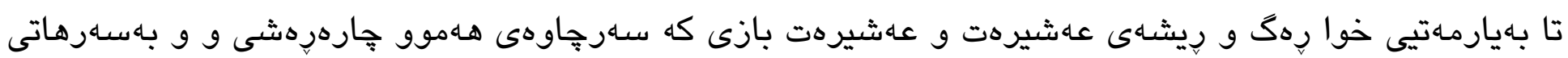

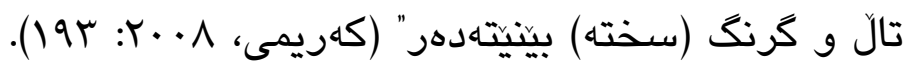

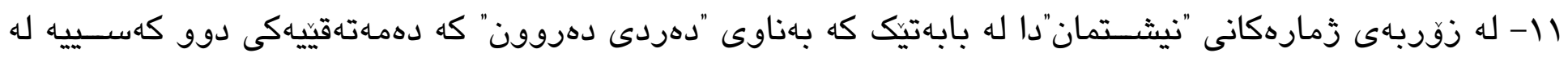

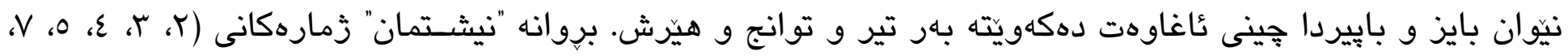

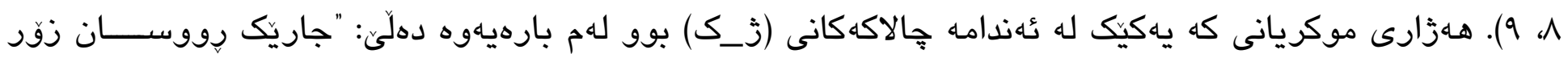

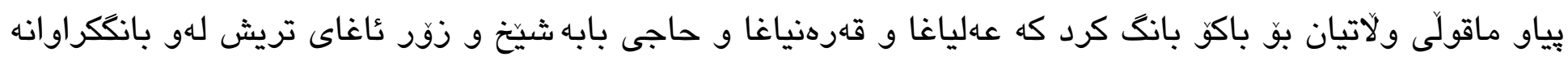

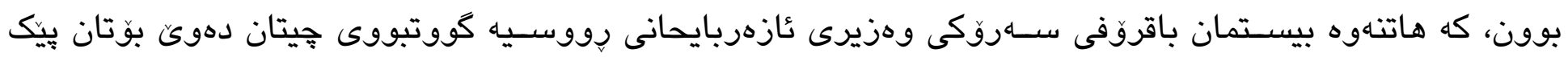

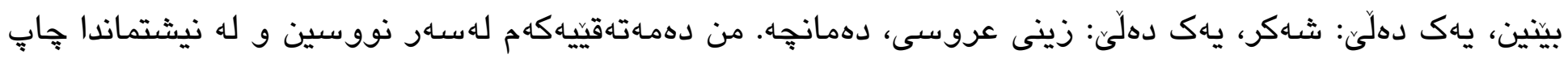

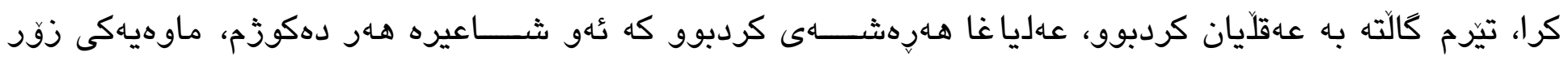

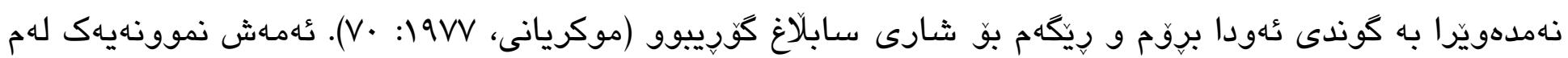
دهماتهقيّيه:

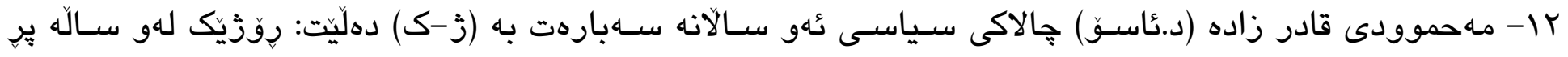

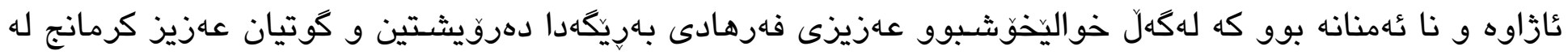

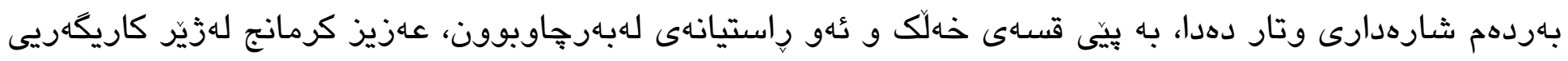

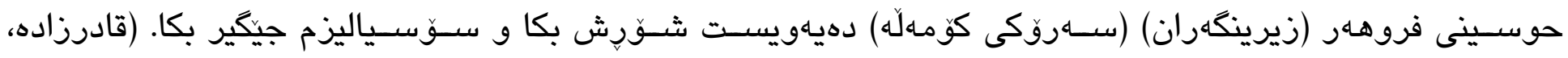

(r)

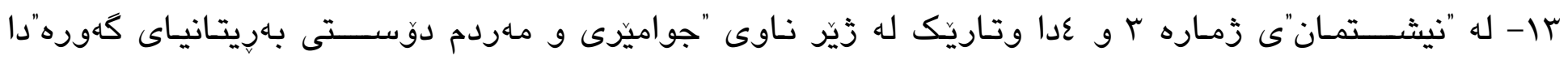

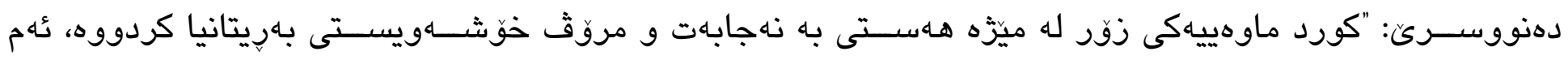

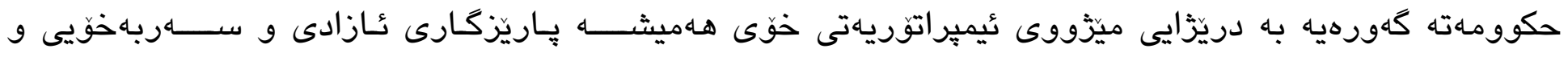

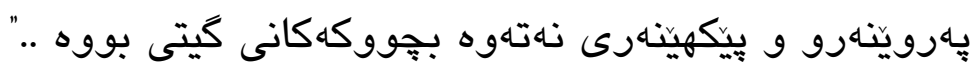

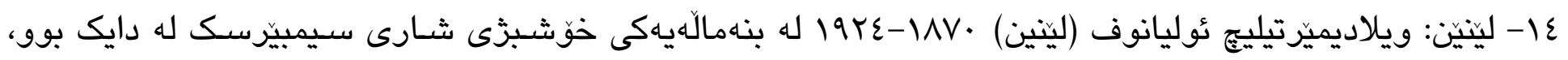

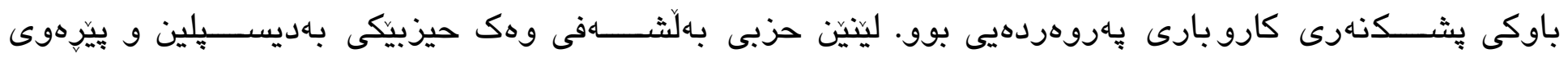




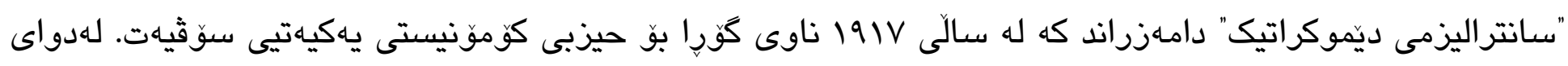

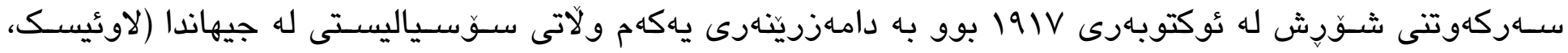

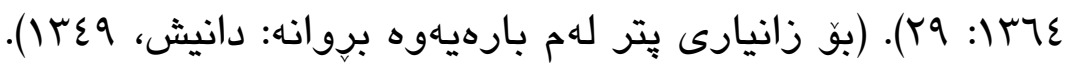

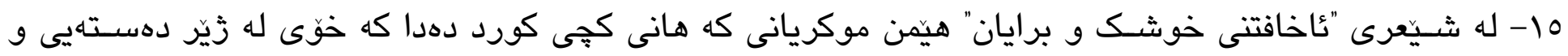
ديلى رِكاربكا، دهلّي:

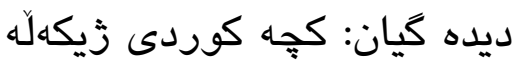

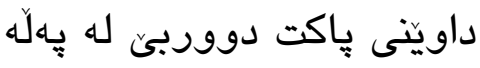

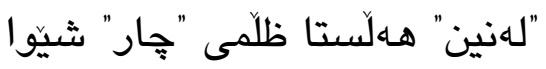

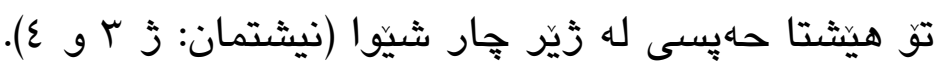

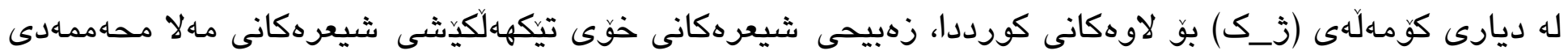

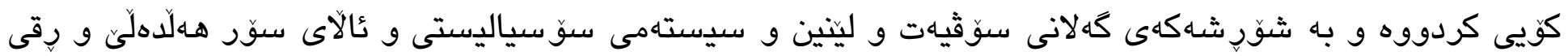

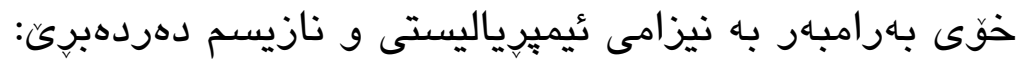

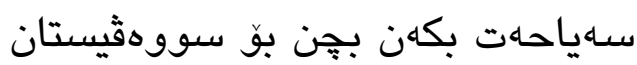

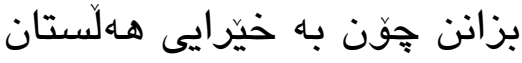

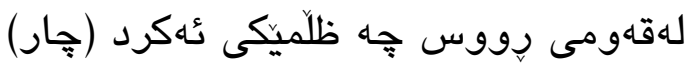

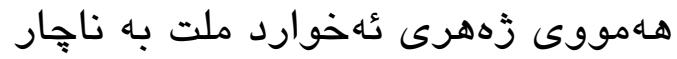

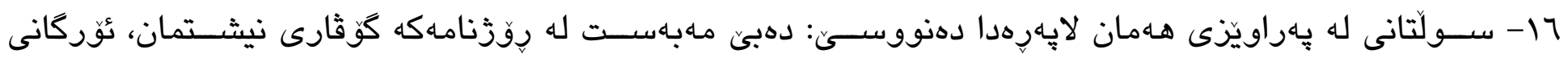

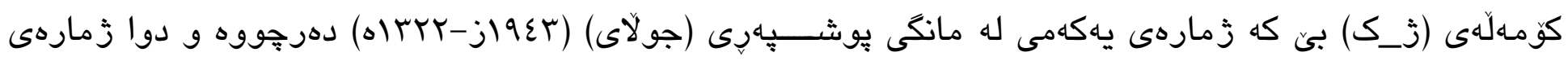

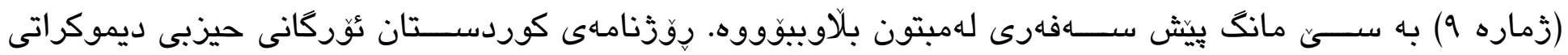

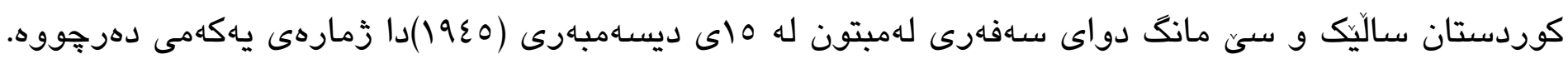

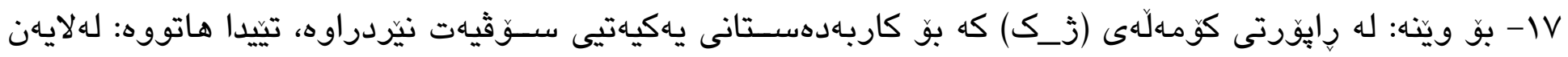

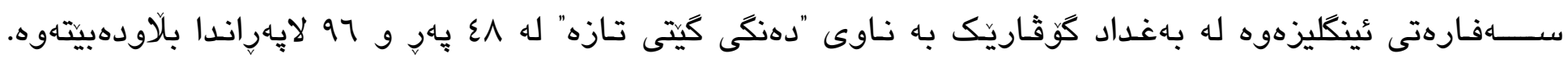

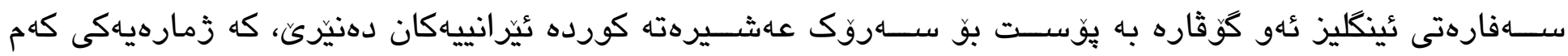

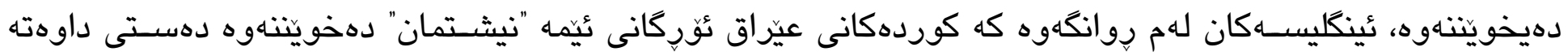

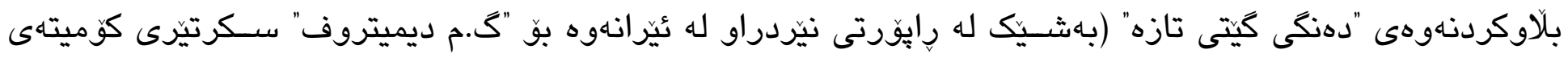

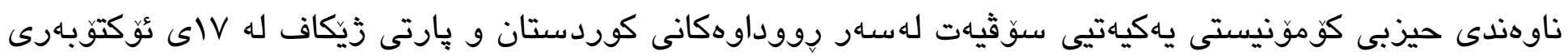

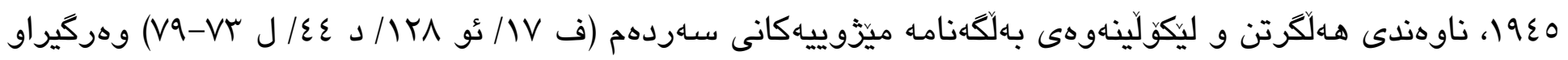

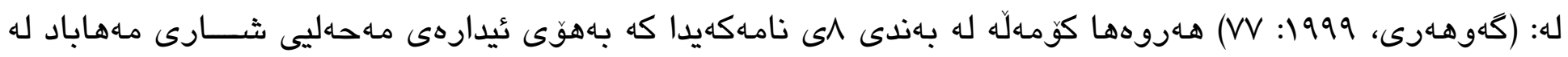

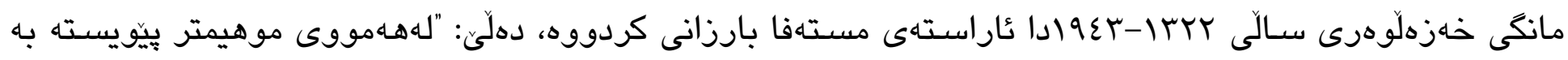

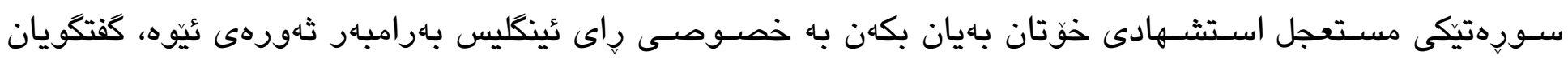

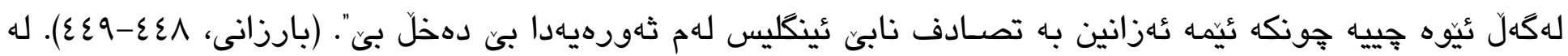

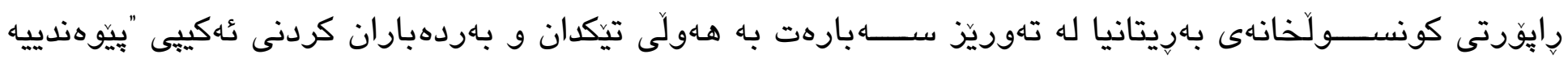

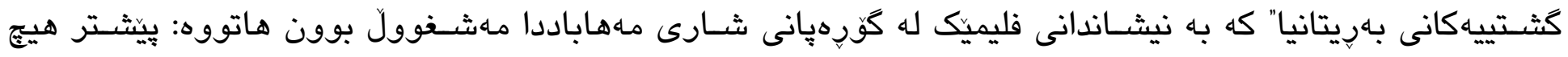

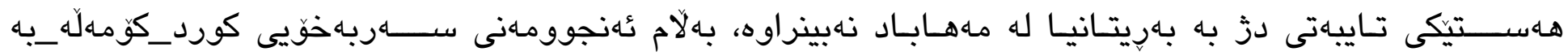




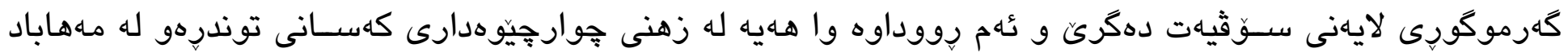

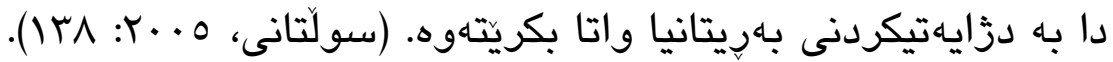

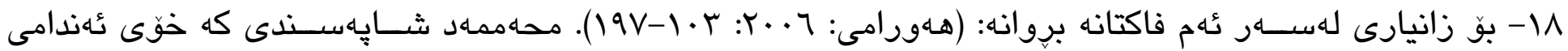

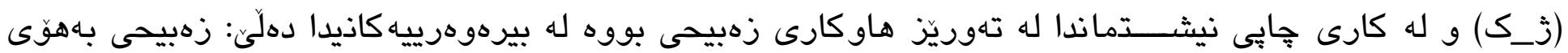

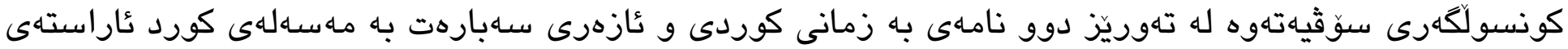

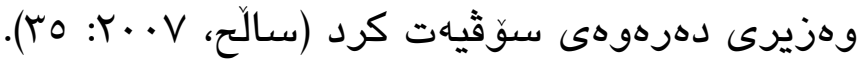

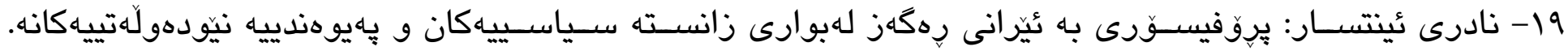

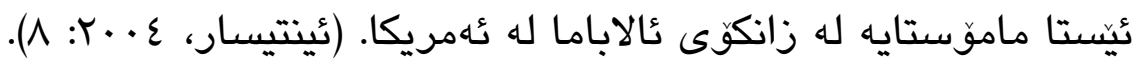

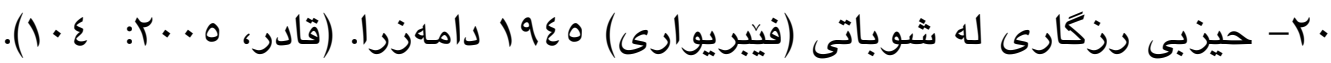

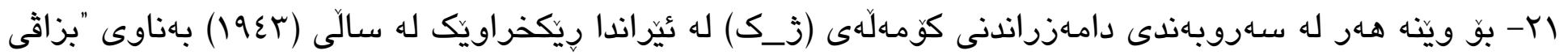

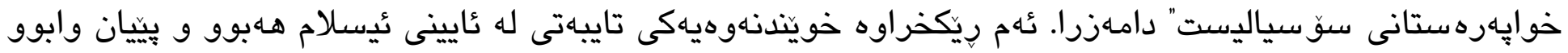

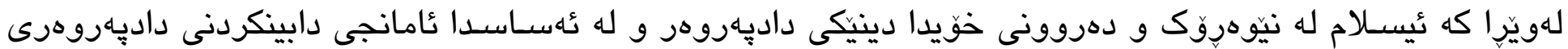

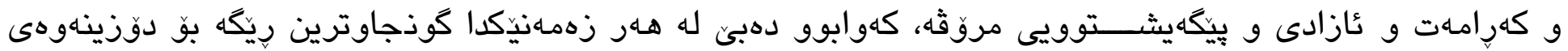

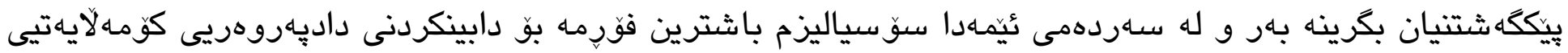

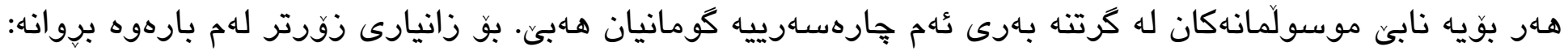

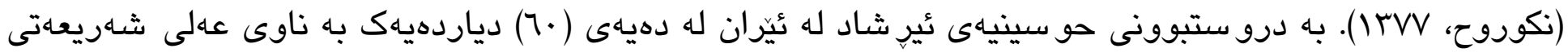

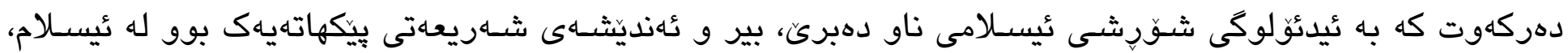

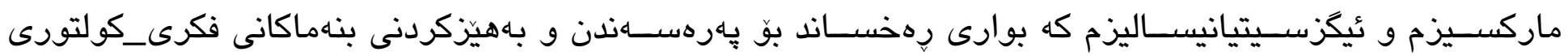

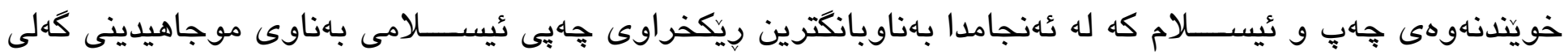

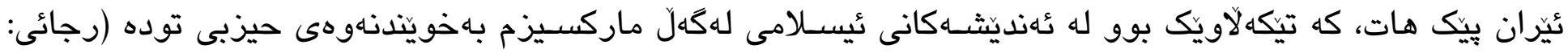

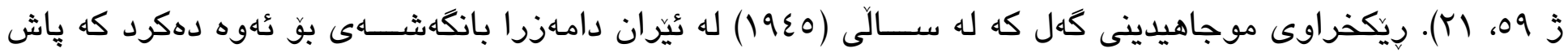

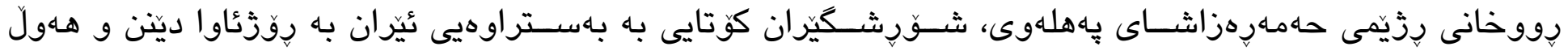

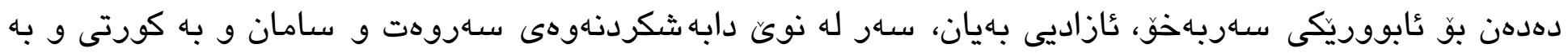

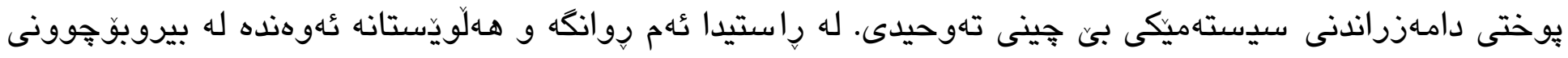

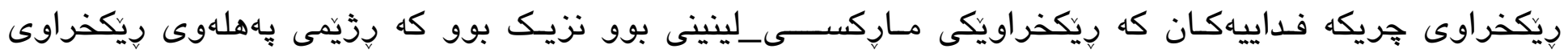

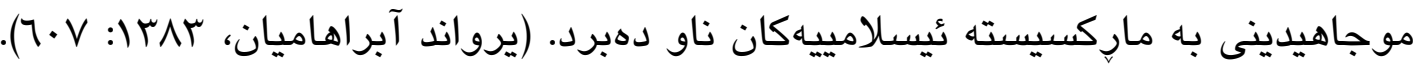

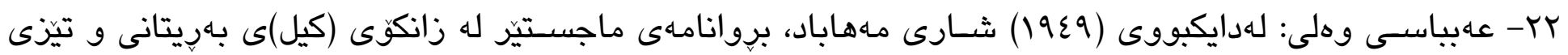

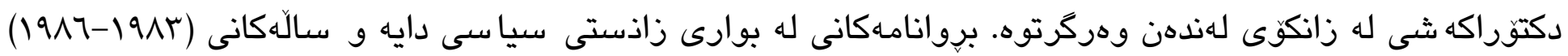

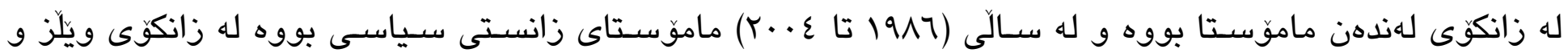

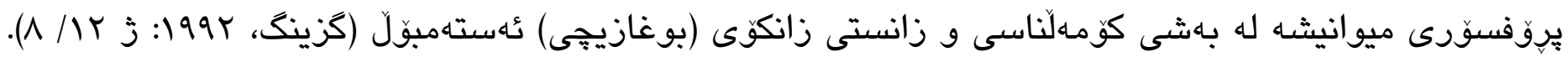

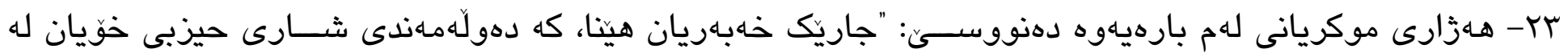

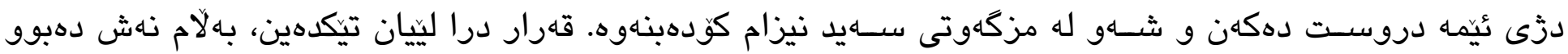

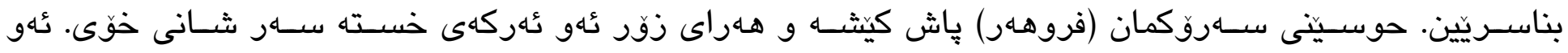

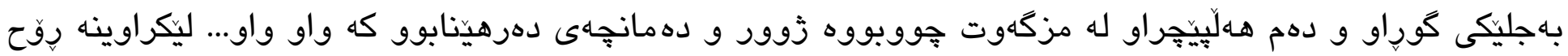




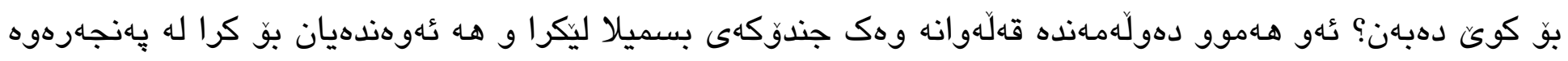

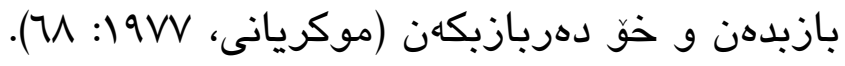

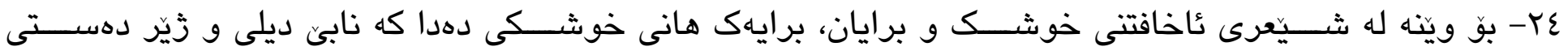

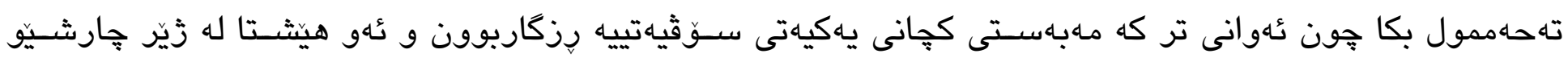

ديده كَيان: كجه كوردى زيكهله

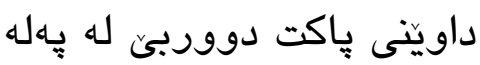

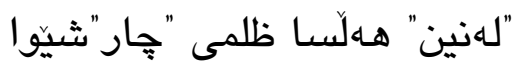

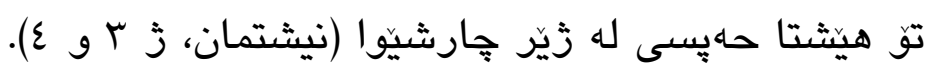

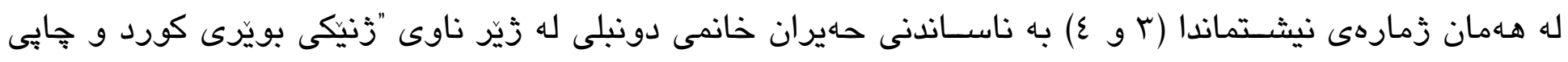

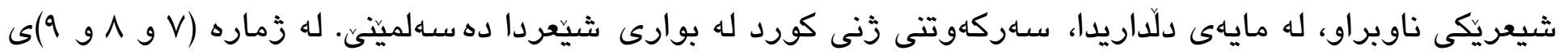

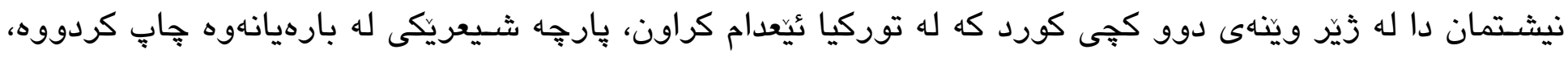
كه بهاه بـهيته كوَتايى ديّت:

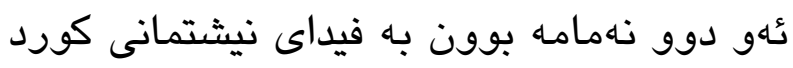

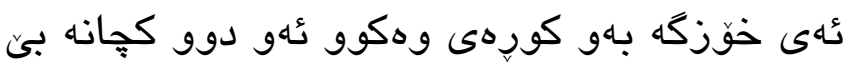

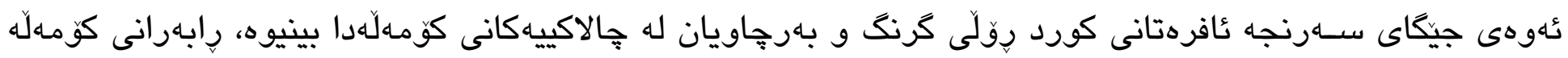

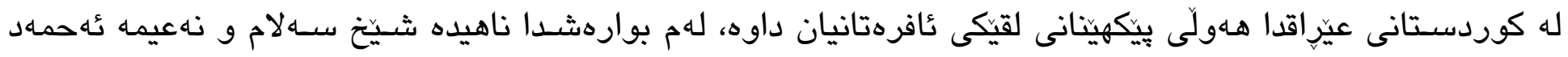

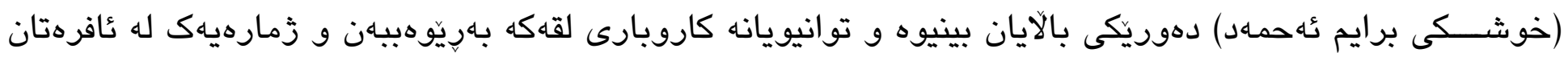

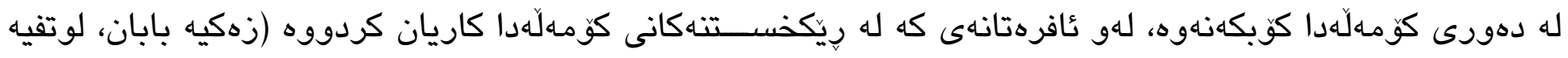

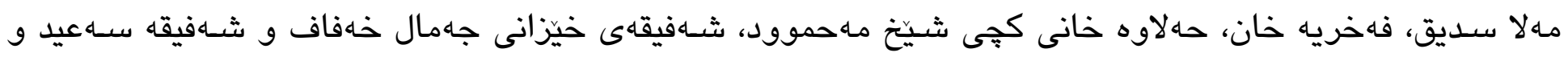

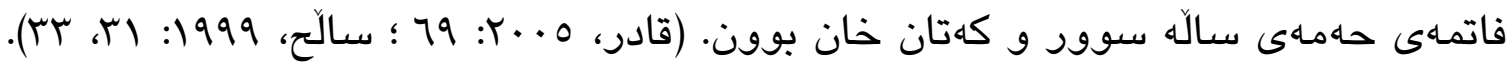

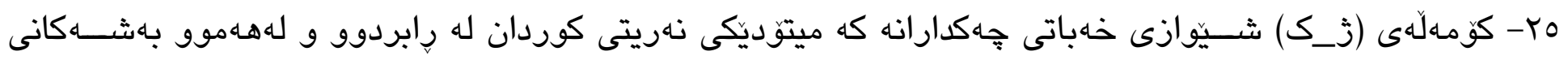

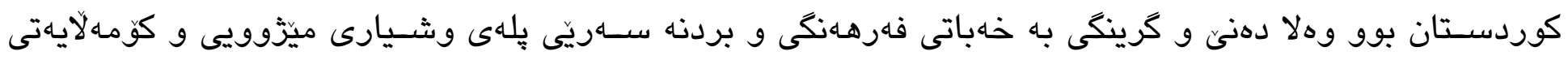

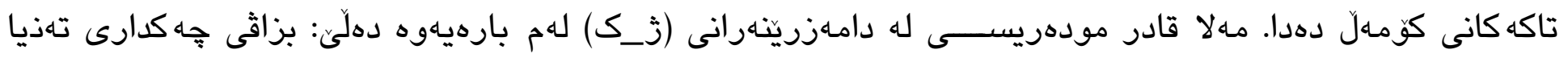

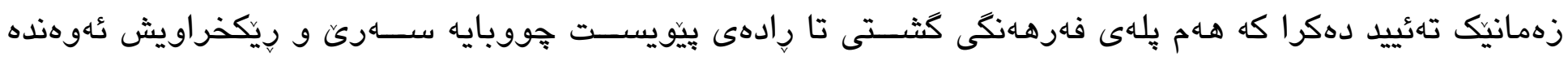

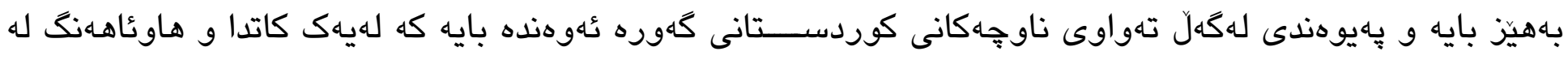

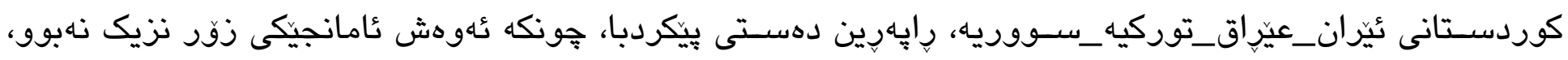

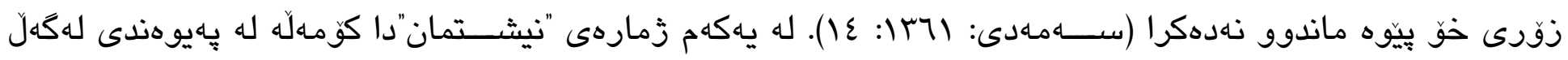

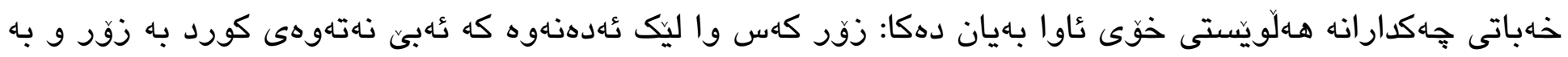

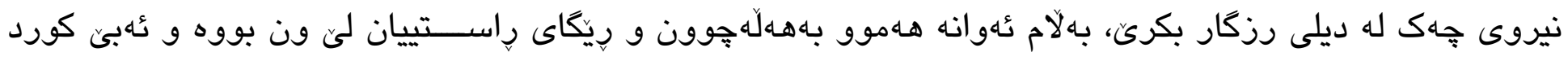

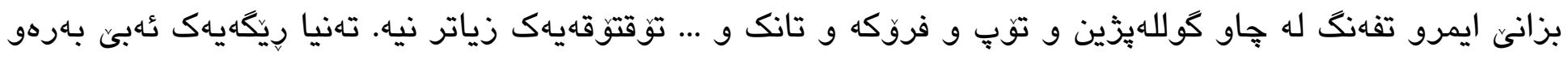

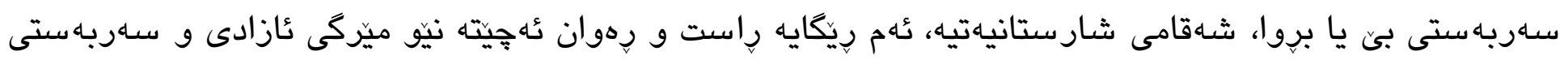

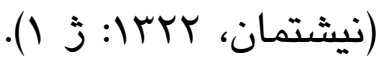




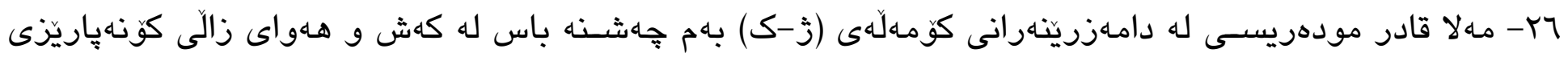

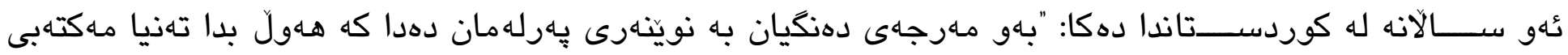

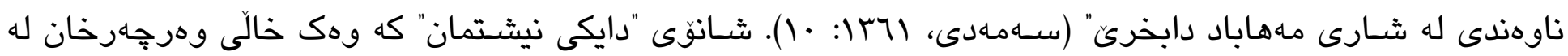

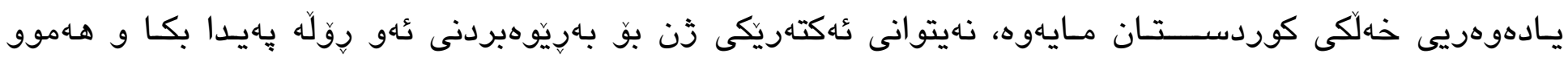

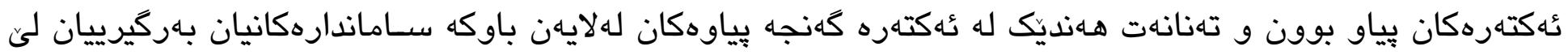

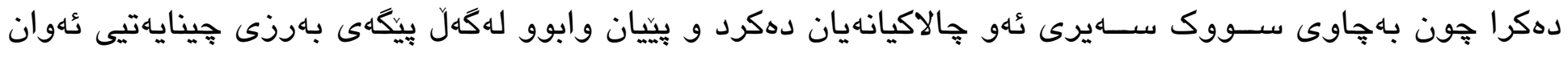

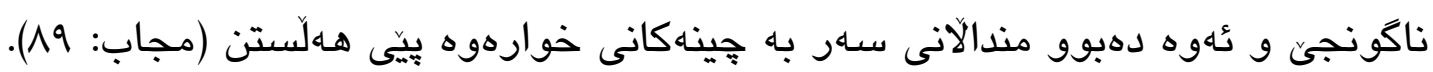

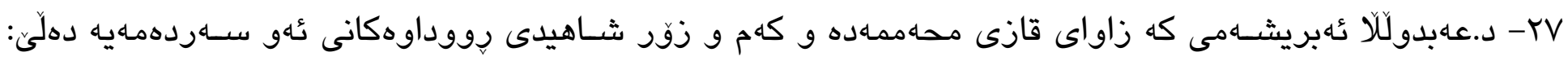

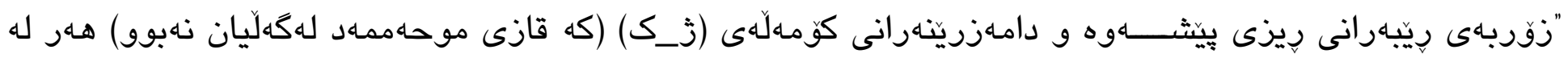

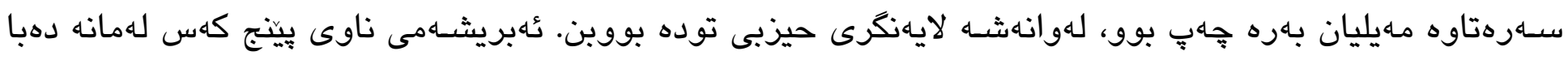

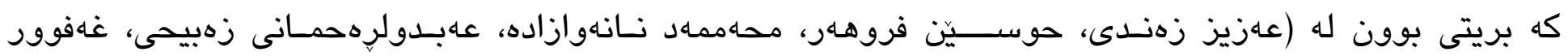

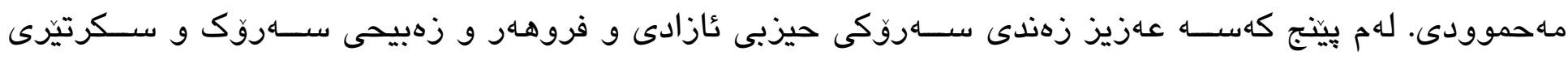

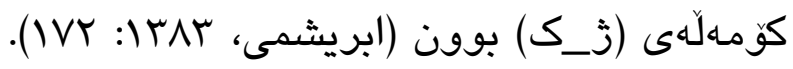




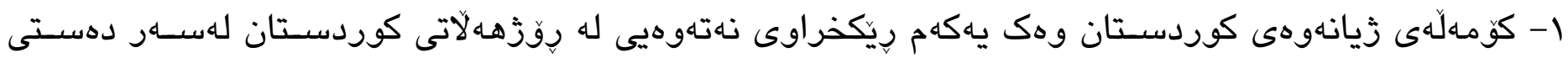

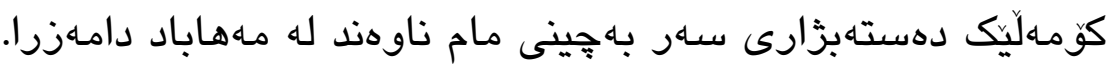

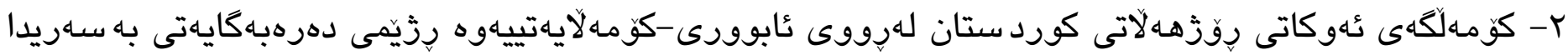

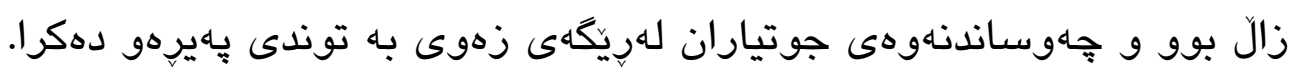

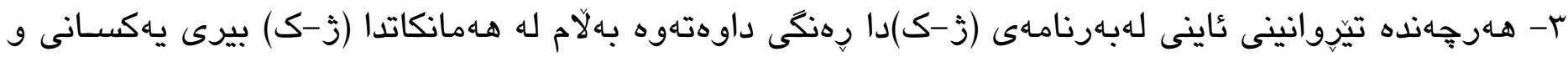

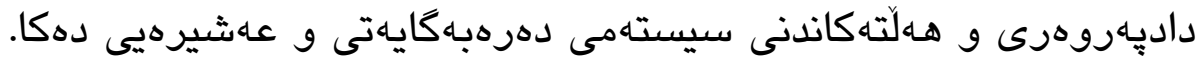

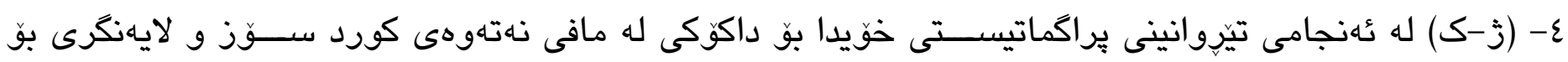
يهكيهتى سوقيهات هـاهيه.

دخل الفكر اليساري كوردستان بطرق مختلة منها الحزب الشيوعي الايراني، حزب تودة و دخول قوات الجيش الاحمر الى ايران للدفاع عن جمهورية كوردستان. الدعاية اليسارية للعدالة ومقاومة الظلم والاستبداد جذب انتباه طبقة النخبة والمثقفين الكورد اليساريين.

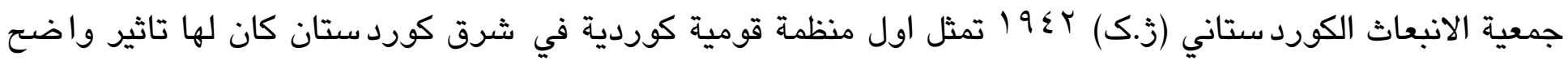
رغم الانطباع عنها كمنظمة قومية دينية كانت متاثرة بالفكر اليســاري الى حد مهاجمة النظام الاقطاعي في كوردســـان كنظام اقتصادي واجتماعي وفي ذات الوقت اعلن دعمـه لطبقة الكادحين لاسيما الفلاحين.

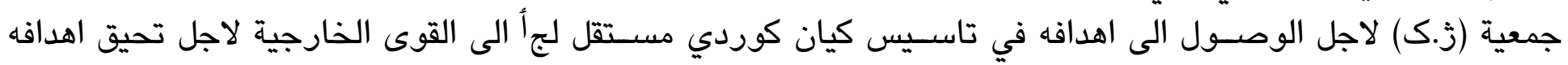

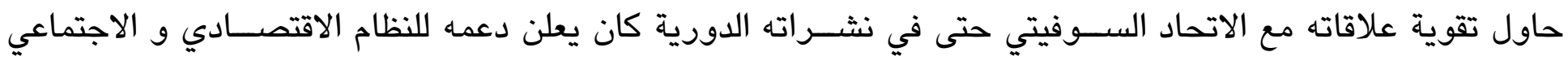
المعمول به في الاتحاد السوفيتي حينذاك.

\section{The impact of leftist on political movement of Eastern Kurdistan: JK (194201945)}




\section{Ismael Abdalrahman Saeed \\ Department of History, faculty of Education, koya university,Koya, kurdistan region, Iraq. \\ Email: ismael.abdalrahman@koyauniversity.org}

\section{Abstract:}

Leftism ideology came to Kurdistan through different ways like; social democracy movement, Iranian Communist Party, Iranian Tuddeh Party and invasion of Kurdistan by the red army and the support of the Soviet Union for the Kurdistan Republic.

Since the leftism idea promoted justice and equality and removal of all kinds of oppression, it was attractive to the Kurdish intellectuals and so they welcomed it: the Kurdistan Revival association as the first nationalist party of Kurdistan (I9\&Y). In spite of this, it was a national-religious party, but the effect of left thoughts was clear. In that order they were against to the feudalism system as an socioeconomic regime of Kurdistan, and they tried to destroy tribal system in Kurdistan and at the same time they supported grubber class and specially farmer class.

Kurdistan Revival Association to reach its main goal meaning creating a Kurdish Independent Government, was looking for foreign support, hence, its relations with the Soviet Union were very friendly and; even in its declarations, there are sympathize for socioeconomic system of Soviet Union.

key words: Right wings, Leftism, Nationalism, Feudalism, JK (Kurdistan Revival Association) 


\section{ليستى سله رجاومكان:}

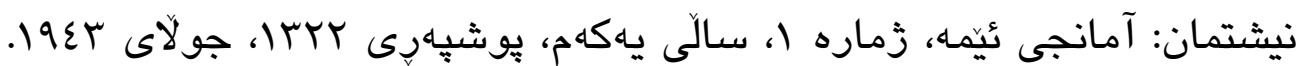

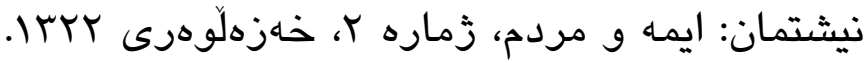

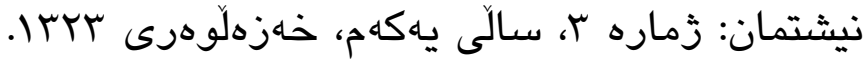
نيثتمان: زماره ع سالّ يهكهم، سبrا. نيشتمان: زماره ه، سالّى يهكهم، ريِّبهندانى سبrا.

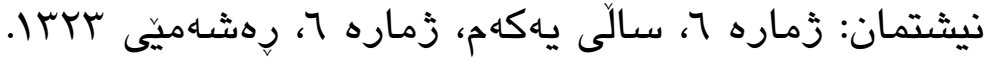
نيشتمان: زماره V، سالّى يهكهم، خاكهليّوه، بانهمهار، جوزهردانى عبrا.

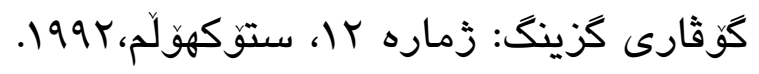

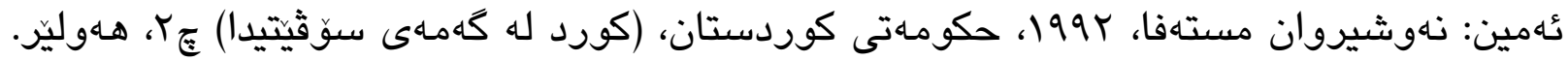

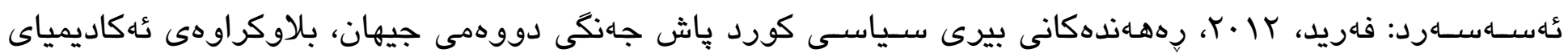
هوَشيارى و بِيكَهانياندنى كاديران، سليمانى.

ئينتسار: نادر، ع..r، ئيتونهتهوايهتيى كوردى، و: عهات قهرهداخى، جإيخانهى تيشك، سليمانى.

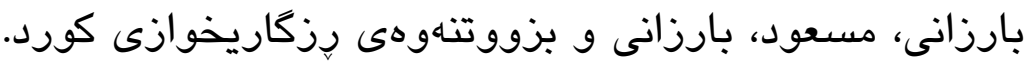

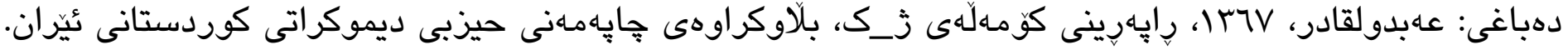

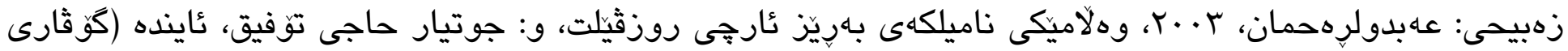

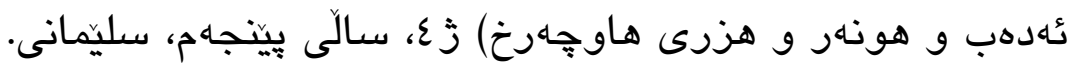




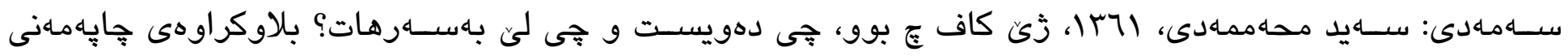
سكييديان، مهاهاباد.

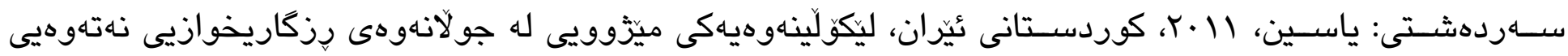

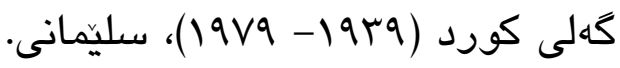

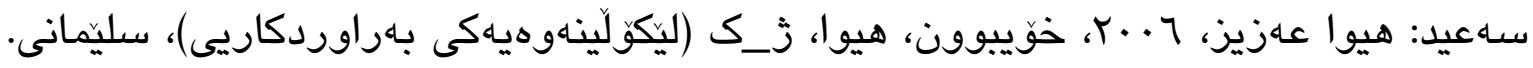

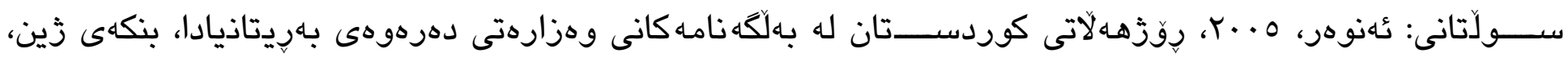
سليمانى.

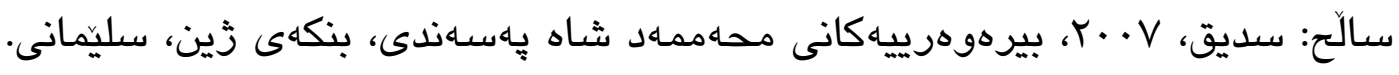

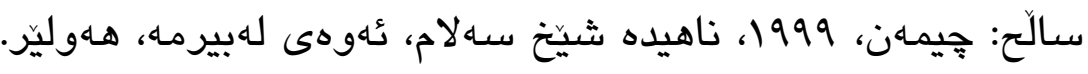

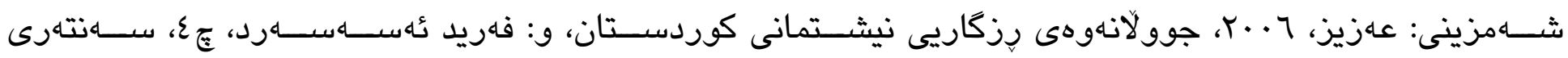
ليكولَينهوهى ستراتيجى كوردستان، سلينمانى.

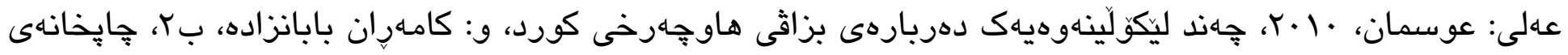
رِيَنويْن، سليَمانى. عوسن.

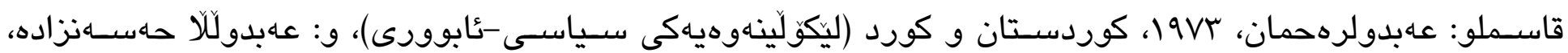
بهاء بداد.

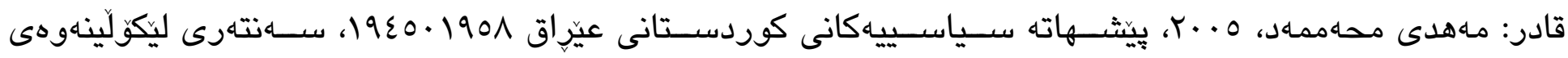
ستراتيجى كوردستان، سليمانى.

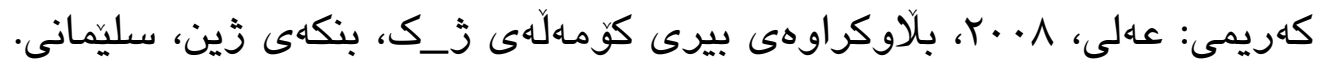

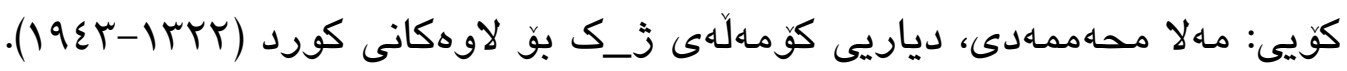

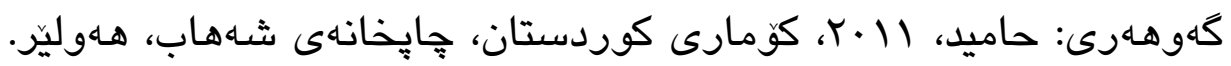

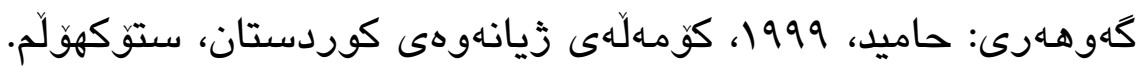

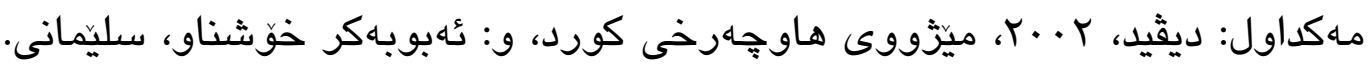
$r \cdot \tau$ 


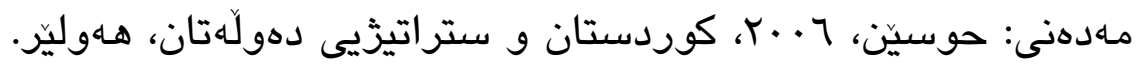

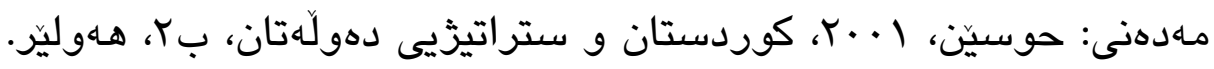

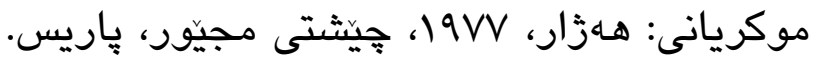

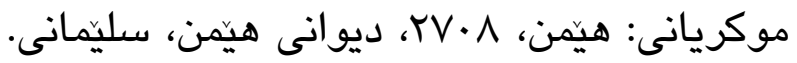

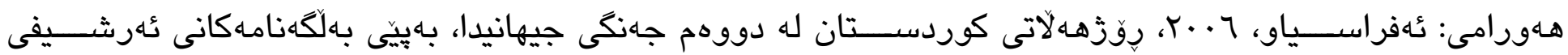

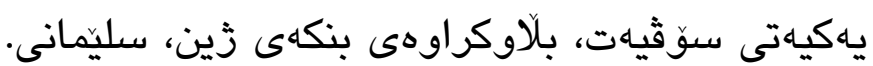
وهلى: عهبياسى، 1990، يهيدابوون و بناغهى ناسيّناليزمى كوردى له ئيران، و: حهسان قازى، سويد. ابراهاميان: يرواند، זییז، ايران بين دوو انقلاب، ترجمه: احمد كل محمدى و محمد ابراهيم فتاحى، جاب نهم، تهران.

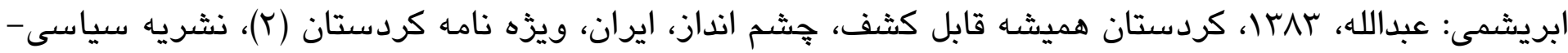
راهبردى.

باباخانى: ناسر، IrVA، عبدلرحمان زبيحى كاريزمايى ناتمام، انتشارات سيديان، مهاباد. خديو: صلاح الدين، .... در دفاع از تاريخ (نقدى بر مقاله احسان هوشمند در جشم انداز ايران).

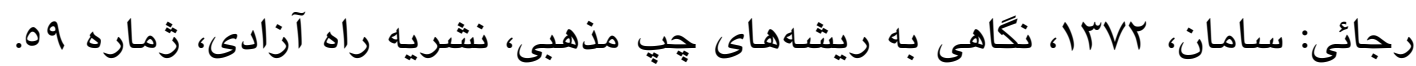

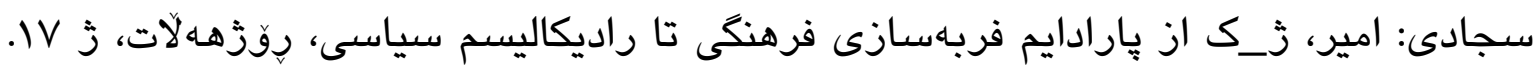

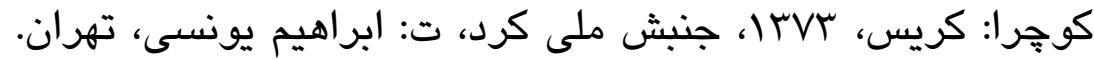

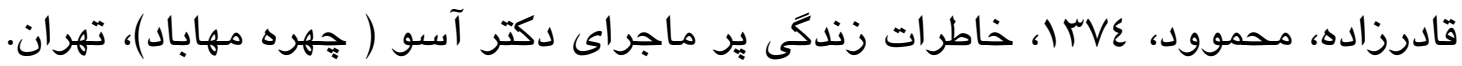

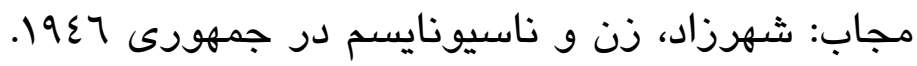

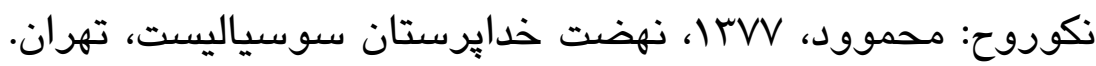

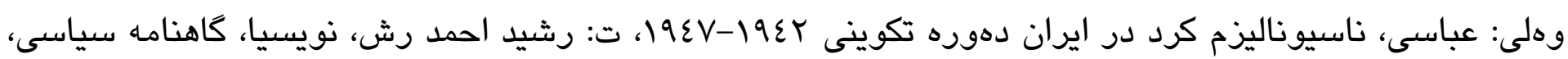

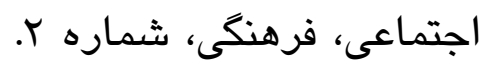
صمدى: سيد محمد، نكاهى بهاره تاريخ مهاباد، انتشارات رهرو مهاباد. احمد: كمال مظهر، 1910، دراسات فى التاريخ ايران الحديث و المعاصر، الامانه العامه الثقافه و الشباب، بغداد. 